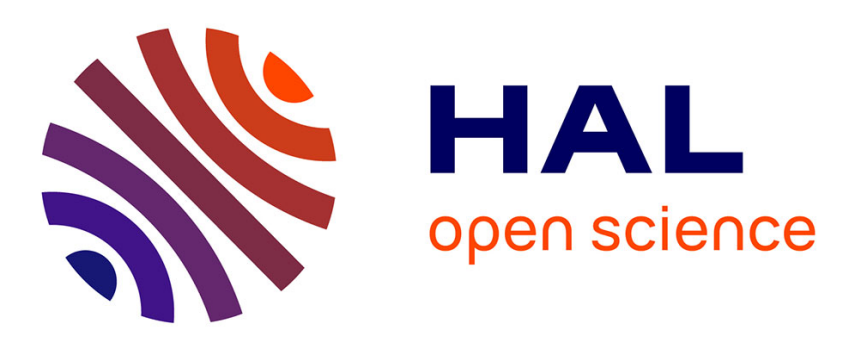

\title{
Economy, Society, and Daily Life in the Old Assyrian Period
}

\author{
Cécile Michel
}

\section{To cite this version:}

Cécile Michel. Economy, Society, and Daily Life in the Old Assyrian Period. A COMPANION TO ASSYRIA (Eckart Frahm dir.), 2017. halshs-02421686

\section{HAL Id: halshs-02421686 \\ https://shs.hal.science/halshs-02421686}

Submitted on 7 Jan 2020

HAL is a multi-disciplinary open access archive for the deposit and dissemination of scientific research documents, whether they are published or not. The documents may come from teaching and research institutions in France or abroad, or from public or private research centers.
L'archive ouverte pluridisciplinaire $\mathbf{H A L}$, est destinée au dépôt et à la diffusion de documents scientifiques de niveau recherche, publiés ou non, émanant des établissements d'enseignement et de recherche français ou étrangers, des laboratoires publics ou privés. 


\section{A COMPANION TO ASSYRIA}

Edited by

Eckart Frahm 
This edition first published 2017

(C) 2017 John Wiley \& Sons Ltd

All rights reserved. No part of this publication may be reproduced, stored in a retrieval system, or transmitted, in any form or by any means, electronic, mechanical, photocopying, recording or otherwise, except as permitted by law. Advice on how to obtain permission to reuse material from this title is available at http://www.wiley.com/go/permissions.

The right of Eckart Frahm to be identified as the author of the editorial material in this work has been asserted in accordance with law.

\section{Registered Offices}

John Wiley \& Sons, Inc., 111 River Street, Hoboken, NJ 07030, USA

John Wiley \& Sons Ltd, The Atrium, Southern Gate, Chichester, West Sussex, PO19 8SQ, UK

\section{Editorial Office}

350 Main Street, Malden, MA 02148-5020, USA

For details of our global editorial offices, customer services, and more information about Wiley products visit us at www.wiley.com.

Wiley also publishes its books in a variety of electronic formats and by print-on-demand. Some content that appears in standard print versions of this book may not be available in other formats.

\section{Limit of Liability/Disclaimer of Warranty}

While the publisher and author have used their best efforts in preparing this book, they make no representations or warranties with respect to the accuracy or completeness of the contents of this book and specifically disclaim any implied warranties of merchantability or fitness for a particular purpose. It is sold on the understanding that the publisher is not engaged in rendering professional services and neither the publisher nor the authors shall be liable for damages arising herefrom. If professional advice or other expert assistance is required, the services of a competent professional should be sought.

\section{Library of Congress Cataloging-in-Publication Data}

Name: Frahm, Eckart, editor.

Title: A companion to Assyria/edited by Eckart Frahm, Yale University, New Haven, US.

Description: Hoboken, NJ : John Wiley \& Sons, 2017. | Series: Blackwell companions to the ancient world | Includes bibliographical references and index.

Identifiers: LCCN 2016046160 (print) | LCCN 2016050443 (ebook) | ISBN 9781444335934 (cloth) | ISBN 9781118325247 (pdf) | ISBN 9781118325230 (epub)

Subjects: LCSH: Assyria-History. | Assyria-Civilization. | Assyria-Antiquities. | Civilization, Assyro-Babylonian. Classification: LCC DS71 .C59 2017 (print) | LCC DS71 (ebook) | DDC 935/.03-dc23

LC record available at https://lccn.loc.gov/2016046160

Cover Design: Wiley

Cover Image: (C) duncan1890/Gettyimages

Set in 10/12.5pt Galliard by SPi Global, Pondicherry, India

Printed in Great Britain by TJ International Ltd, Padstow, Cornwall.

$\begin{array}{llllllllll}10 & 9 & 8 & 7 & 6 & 5 & 4 & 3 & 2 & 1\end{array}$ 


\section{Contents}

Notes on Contributors

viii

Acknowledgments

xiii

Introduction

Eckart Frahm

$\begin{array}{ll}\text { Part I Geography and History } & 11\end{array}$

1 Physical and Cultural Landscapes of Assyria 13 Jason Ur

2 "Assyria" in the Third Millennium BCE 36 Lauren Ristvet

3 The Old Assyrian Period (20th-18th Century BCE) 57 Klaas R. Veenhof

4 Economy, Society, and Daily Life in the Old Assyrian Period 80 Cécile Michel

5 The Transition Period (17th to 15th Century BCE) 108 Shigeo ramada

6 The Middle Assyrian Period (14th to 11th Century BCE) 117 Stefan Jakob

7 Economy, Society, and Daily Life in the Middle Assyrian Period 143 Stefan Jakob

8 The Neo-Assyrian Period (ca. 1000-609 BCE) Eckart Frabm 
9 Economy, Society, and Daily Life in the Neo-Assyrian Period Karen Radner

10 Post-Imperial Assyria Stefan R. Hauser

\section{Part II The Fringes of Empire: Assyria and its Neighbors}

11 Assyria and the North: Anatolia

Andreas Fuchs

12 Assyria and the East: Western Iran and Elam Andreas Fuchs

13 Assyria and the West: Syria and the Levant Ariel M. Bagg

14 Assyria and the Far West: The Aegean World

Robert Rollinger

15 Assyria and the South: Babylonia

Eckart Frabm

16 Assyria and the Far South: The Arabian

Peninsula and the Persian Gulf

Eckart Frabm

\section{Part III Elements of Assyrian Civilization}

17 Languages and Writing Systems in Assyria

Mikko Luukko and Greta Van Buylaere

18 Assyrian Religion

Stefan M. Maul

19 Assyrian Literature

Alasdair Livingstone

20 Assyrian Scholarship and Scribal Culture in Ashur

Nils P. Heeßel

21 Assyrian Scholarship and Scribal Culture in Kalhu and Nineveh Jeanette C. Fincke

22 Assyrian Legal Traditions

Frederick Mario Fales

23 Assyrian Cities and Architecture

John M. Russell

24 Assyrian Art

John M. Russell

25 Assyrian Technology 
26 Assyrian Warfare

Stephanie Dalley

27 Thoughts on the Assyrian Empire and Assyrian Kingship Mario Liverani

Part IV The Afterlife and Rediscovery of Assyria

28 Assyria in Late Babylonian Sources

Paul-Alain Beaulien

29 Assyria in the Hebrew Bible Eckart Frahm

30 Assyria in Classical Sources Robert Rollinger

31 The Archaeological Exploration of Assyria Mogens Trolle Larsen

32 Assyrian Christians Aaron Michael Butts

List of Assyrian Kings

Eckart Frahm

Index 


\section{Notes on Contributors}

Ariel M. Bagg is private lecturer at the Assyriological Institute of the RuprechtKarls-Universität Heidelberg (Germany) and member of the Centre François Viète d'épistémologie et d'histoire des sciences et des techniques (Brest/Nantes, France). $\mathrm{He}$ is an Assyriologist and Civil Engineer specializing in ancient Near Eastern history of technology and historical geography of the first millennium. His publications include Assyrische Wasserbauten (2000), Die Ortsund Gewässernamen der neuassyrischen Zeit. Teil 1: Die Levante (2007), and Die Assyrer und das Westland (2011).

Paul-Alain Beaulieu received his $\mathrm{PhD}$ in Assyriology from Yale University in 1985 and held various research and teaching positions at Yale, Harvard, and the University of Notre Dame before joining the faculty of the Department of Near and Middle Eastern Civilizations in the University of Toronto in 2006. He has published extensively on the history and culture of Mesopotamia in the first millennium $\mathrm{BCE}$, notably The Reign of Nabonidus, King of Babylon (556-539 BC) (1989) and The Pantheon of Uruk During the Neo-Babylonian Period (2003).
Aaron Michael Butts (PhD University of Chicago) is an Assistant Professor in the Department of Semitic and Egyptian Languages and Literatures at the Catholic University of America. His research focuses on the history, languages, and literature of Christianity in the Near East, including Arabic, Ethiopic, and especially Syriac Christianity. $\mathrm{He}$ is author of Language Change in the Wake of Empire: Syriac in its Greco-Roman Context (2016) and a coeditor of the Gorgias Encyclopedic Dictionary of the Syriac Heritage (2011).

Greta Van Buylaere (PhD Udine 2009) studied Assyriology in Leuven, Heidelberg, Helsinki, and Udine. At present, she is a researcher in the project "Corpus of Mesopotamian Anti-Witchcraft Rituals" directed by Daniel Schwemer at the University of Würzburg. She is interested in Assyrian and Babylonian literacy, and the political and intellectual history of first millennium BCE Mesopotamia in general.

Stephanie Dalley is an Assyriologist who taught Akkadian for thirty years at Oxford University, and has published Assyrian 
cuneiform tablets from Nimrud, Nineveh, Tell al-Rimah, Til Barsip, as well as Babylonian texts from Sippar and of the First Sealand Dynasty; also translations of the main myths and epics, Myths from Mesopotamia (1989), an analysis of the Assyrian background to the Hebrew Book of Esther, Esther's Revenge at Susa (2007), and The Mystery of the Hanging Garden of Babylon: An Elusive World Wonder Traced (2013).

Frederick Mario Fales, born in Baltimore in 1946, has been Full Professor of ancient Near Eastern History at the University of Udine (Italy) since 1994. His main scholarly interests concern Mesopotamia in the $\mathrm{NeO}^{-}$ Assyrian period (10th-7th centuries BCE) and range from historical studies to editions of Assyrian and Aramaic texts. He has undertaken, and sometimes directed, archaeological activities in Iraq, Syria, Turkey, and Iraqi Kurdistan. He founded an international journal on Neo-Assyrian studies, the State Archives of Assyria Bulletin, and the monographic series History of the Ancient Near East (SARGON: Padua). His publications include twelve monographs, seven edited volumes, and some 170 articles. For bibliography up to 2011 see https://uniud. academia.edu/MarioFales.

Jeanette C. Fincke (PhD Würzburg: 1999; habilitation Heidelberg: 2006) has been conducting research on the British Museum's collection of Nineveh texts for its Ashurbanipal Library Project in the past years, concentrating on divinatory texts and tablets written in the Babylonian ductus. Her work resulted in producing new databases (see www.fincke-cuneiform.com/nineveh/ index.htm) and several articles. Currently, she is chercheur for the ERC project Floriental at the Centre nationale de la recherche scientifique (CNRS) in Paris, where she focuses on the pharmaceutical series URU.AN.NA from the first millennium BCE.
Eckart Frahm (PhD Göttingen 1996, habilitation Heidelberg 2007) is Professor of Assyriology at Yale University. His main research interests are Assyrian and Babylonian history and Mesopotamian scholarly texts of the first millennium BCE. Frahm is the author of numerous articles and five books: Einleitung in die Sanberib-Inschriften (1997), Keilschrifttexte aus Assur literarischen Inhalts, vol. 3 (2009), NeoBabylonian Letters and Contracts from the Eanna Archive (2011, co-authored with Michael Jursa), Babylonian and Assyrian Text Commentaries: Origins of Interpretation (2011), and Geschichte desalten Mesopotamien (2013). In addition, he serves as director of the Cuneiform Commentaries Project (http://ccp.yale.edu).

Andreas Fuchs is Professor of Assyriology at the University of Tübingen and a specialist in Neo-Assyrian history. He is the author of Die Inschriften Sargons II. aus Khorsabad (1993), Die Annalen des Jabres 711 v. Chr. nach Prismenfragmenten aus Ninive und Assur (1998), and, together with Simo Parpola, The Correspondence of Sargon II, Part III (2001).

Stefan R. Hauser is Professor for "Archaeology of ancient Mediterranean cultures and their relations to the ancient Near East and Egypt" at the University of Konstanz (Germany). He is editor of Die Sichtbarkeit von Nomaden und saisonaler Besiedlung in der Archäologie (2006) and Ernst Herzfeld and the Development of Near Eastern Studies, 1900-1950 (2005; with A.C. Gunter), and author of Status, Tod und Ritual. Stadt- und Sozialstruktur Assurs in nenassyrischer Zeit (2012). He currently directs projects on burial practices and the art of the portrait in Palmyra and on religion and identity in Hellenistic Mesopotamia. A Handbook of the Arsacid Empire is in preparation. 
Nils P. Heeßel is Professor of Assyriology at the Julius-Maximilians University Würzburg. $\mathrm{He}$ is a specialist for the Akkadian scholarly tradition, in particular for scientific and divinatory texts. His publications include Babylonisch-assyrische Diagnostik (2000), Pazuzu (2002), and Divinatorische Texte I and $I I(2007,2012)$.

Stefan Jakob studied Assyriology, Near Eastern Archaeology, and Musicology at the University of Saarbrücken and received his $\mathrm{PhD}$ degree in 2000 for research on Middle Assyrian administration and social structure. Between 1992 and 2003 he served as a staff member of several excavation projects (Tell Chuera and Tell Shekh Hassan in Syria and Qantir/Pi-Ramesse in Egypt). Since 2004 he has been a research assistant in Assyriology at the Institute for Cultures and Languages of the Middle East, University of Heidelberg. His main interests are Middle Assyrian history and chronology. In recent years he also worked on Assyrian prayers and ritual texts.

Mogens Trolle Larsen, Emeritus Professor of Assyriology at the University of Copenhagen, is a specialist in the history and culture of the Old Assyrian period. His most recent book is Ancient Kanesh: A Merchant Colony in Bronze Age Anatolia (2015).

Mario Liverani is Emeritus Professor of History of the Ancient Near East at the University of Rome "La Sapienza." $\mathrm{He}$ is former director of the Institute of Near Eastern Studies, of the Department of Sciences of Antiquity, and of the InterUniversity Center on the Ancient Sahara, in the same "Sapienza" University. He has received honorary doctorates from the Universities of Copenhagen and Madrid, is a honorary member of the American Oriental Society, and member of the Lincei National Academy (Rome), of the Academy of
Sciences (Turin), and of the European Academy. He was a member of archaeological missions in Syria (Ebla, Terqa, Mozan), Turkey (Kurban, Arslantepe), Yemen (Baraqish), and Libya (Akakus). He is author of nineteen monographs and ca. 260 articles, and the editor of eight books.

Alasdair Livingstone is Reader in Assyriology at the University of Birmingham and a specialist in cuneiform scholarly and literary texts, especially from Assyria. His publications include Mystical and Mythological Explanatory Works of Assyrian and Babylonian Scholars (1986) and Hemerologies of Assyrian and Babylonian Scholars (2013).

Mikko Luukko studied Assyriology, Semitics, and Linguistics at the University of Helsinki and the Freie Universität Berlin. In 2004, he gained his PhD from Helsinki, with a study of "Grammatical Variation in Neo-Assyrian." Luukko is currently working on a research project entitled "Corpus of Mesopotamian Anti-witchcraft Rituals," directed by Daniel Schwemer at the University of Würzburg. He has published monographs and articles on Neo-Assyrian letters and Assyrian grammar, including The Correspondence of Tiglath-pileser III (2013).

Stefan M. Maul is Professor of Assyriology at the University of Heidelberg. His research focuses on Assyrian and Babylonian religion and intellectual life; over the past years, his main project has been the edition of the literary and scholarly texts from Ashur. Maul's books include “Herzberuhigungsklagen”: Die sumerischakkadischen Eršabunga-Gebete (1988), Zukunftsbewältigung: Eine Untersuchung altorientalischen Denkens anhand der babylonisch-assyrischen Löserituale (Namburbi) (1994), Die Wabrsagekunst im Alten Orient (2013), and Das Gilgamesch-Epos neu 
übersetzt und kommentiert von Stefan $M$. Maul (2014, 6th edn.). In 1997, Maul received the prestigious Gottfried Wilhelm Leibniz Prize for his research.

Cécile Michel is a historian and Assyriologist, Director of Research at the National Center of Scientific Research (CNRS) in the laboratory Archéologies et Sciences de l'Antiquité at Nanterre (France). She is currently heading the International Association for Assyriology (2014-18). Working on the decipherment and study of cuneiform texts from the first half of the 2nd millennium BCE (private archives of merchants, state administrative archives), she has published books and articles on Mesopotamian trade, Upper Mesopotamian and Anatolian societies, gender studies, daily life and material culture (fauna, food, metals, minerals, and textiles), calendars and chronology, history of science, education, writing, and computing.

Karen Radner is Alexander von Humboldt Professor of Ancient History of the Near and Middle East at LMU Munich and Honorary Professor of Ancient Near Eastern History at University College London. She has published extensively on the Assyrian Empire's political, administrative, social, legal, and cultural history. Her books include editions of cuneiform archives from Assur (Iraq), Dur-Katlimmu (Syria), and Dunnu-ša-Uzibi (Turkey), an analysis of Mesopotamian inscriptions as "written names" (Die Macht des Namens: altorientalische Strategien zur Selbsterhaltung, 2005), and Ancient Assyria: $A$ Very Short Introduction (2015), as well as several edited volumes. She currently directs the Peshdar Plain Project in the Kurdish Autonomous Region of Iraq and, together with Jamie Novotny, the Munich Openaccess Cuneiform Corpus Initiative.

Lauren Ristvet is Associate Professor of Anthropology at the University of
Pennsylvania. Her research interests include Near Eastern archaeology, the political transformations of complex societies, and ritual and performance theory. She recently published Ritual, Performance and Politics in the Ancient Near East (2014).

Robert Rollinger is Professor of Ancient History and Ancient Near Eastern Studies at the Leopold-Franzens University at Innsbruck. His main research areas are the history of the ancient Near East and the Achaemenid Empire, contacts between the Aegean World and the ancient Near East, and ancient historiography. Recent publications include: Imperien in der Weltgeschichte. Epochenübergreifende und globalbistorische Vergleiche (co-edited; 2014), Mesopotamia in the Ancient World. Impact, Continuities, Parallels (co-edited; 2015), Alexander und die großen Ströme. Die Flussüberquerungen im Lichte altorientalischer Pioniertechniken (2013).

John M. Russell is Professor of the History of Art at Massachusetts College of Art and Design in Boston. He specializes in the art and architecture of the ancient Near East, in particular the Neo-Assyrian period. His books include Sennacherib's "Palace without Rival" at Nineveh (1991), From Nineveh to New York (1997), The Final Sack of Nineveh (1998), and The Writing On the Wall (1999).

Jason Ur is Professor of Anthropology in the Department of Anthropology at Harvard University, and director of its Center for Geographic Analysis. He specializes in early urbanism, landscape archaeology, and remote sensing, particularly the use of declassified US intelligence imagery. $\mathrm{He}$ has directed field surveys in Syria, Iraq, Turkey, and Iran. He is the author of Urbanism and Cultural Landscapes in Northeastern Syria: The Tell Hamoukar Survey, 1999-2001 (2010). Since 2012, he has directed the Erbil 
Plain Archaeological Survey, an archaeological survey in the Kurdistan Region of northern Iraq. He is also preparing a history of Mesopotamian cities.

Klaas R. Veenhof is Emeritus Professor of Assyriology at Leiden University and a specialist in the history and culture of Mesopotamia during the first half of the second millennium BCE, the so-called Old Assyrian and Old Babylonian periods. His publications include the books Aspects of Old Assyrian Trade and its Terminology (1972), Altassyrische Texte und Tontafeln aus Kültepe (1992), Letters in the Louvre: Altbabylonische Briefe 14 (2005), and part I of Mesopotamia: The Old Assyrian Period (Annäherungen 5, 2008). At the invitation of the director of the Turkish excavations at Kültepe (ancient Kaniš, in Central Anatolia) he has been working on the edition of some of the Old
Assyrian archives found there, publishing, inter alia, The Archive of Kuliya, son of AliAbum (Kültepe Tabletleri V, 2010) and The Old Assyrian List of Year Eponyms from Karum Kanish and its Chronological Implications (2012).

Shigeo Yamada is Professor of History at the University of Tsukuba, where he teaches history and languages of the ancient Near East. He is the author of The Construction of the Assyrian Empire: A Historical Study of the Inscriptions of Shalmaneser III (859-824 $\mathrm{BC}$ ) relating to $H$ is Campaign to the West (2000), and the co-author (with Hayim Tadmor) of The Royal Inscriptions of Tiglath-pileser III and Shalmaneser V, Kings of Assyria (744-722 вC) (2012). He is currently working on the texts unearthed by the Japanese excavations at Tell Taban, Syria. 


\title{
CHAPTER 4
}

\section{Economy, Society, and Daily Life in the Old Assyrian Period}

\author{
Cécile Michel
}

\section{Introduction}

At the beginning of the second millennium BCE, Assyrians originating from Ashur settled in Kaniš and other Anatolian towns. They lived in the lower town of Kaniš with the local population. Almost no tablets from this period have been found in Ashur, whereas the commercial quarter of Kaniš has produced some 22,500 cuneiform tablets, dated predominantly to the level II period (ca. 1945-1835 $\mathrm{BCE}$ ). Only 2 percent of the documentation dates to the later level Ib period (ca. 1832-1700 BCE).

The private archives of the Assyrian merchants, found in their houses in Kanišs lower town, mainly concern the long distance trade they initiated, but also document the everyday life of their community in Anatolia, and, very indirectly, in Ashur. Because no archival texts were found in Ashur itself, we have only very few samples of their marriage contracts or of their last wills, which must have been kept in their houses in the mother city. There is, however, some information in the letters residents of Ashur sent to Kaniš about their religious beliefs, the organization of their households, and their daily occupations. These data may be compared with what we know about the Assyrians living in Kaniš, who left numerous archival texts.

The 22,500 Kaniš texts belong to two or three generations of Assyrian merchants and include letters, legal texts, and private notices (Hertel 2013; Michel 2003; Michel 2008e; Veenhof 2003a; Veenhof 2013). Letters offer data about domestic affairs, while legal texts sometimes deal with family law. The archives also cast light on the Anatolian society of Kaniš, which is, however, not taken into account in this chapter (Dercksen 2004b; Kryszat 2008a, 2008b; Michel 2011a, 2011b, 2014a, 2014b; Veenhof 2008: 147-246).

A major part of Ashur's population seems to have been involved in the international trade in tin and textiles or in the local Anatolian copper and wool trade. The family formed the heart of Old Assyrian society. Letters give an idea of the activities of the various family members, 
including merchant wives, who were often alone in Ashur, managing their households and raising their children. In the family enterprises, almost everyone worked to boost their personal profits (Larsen 2007). Devoting most of their time to the trade, in which even priests and consecrated women were involved, the Assyrians depended on markets and shops to buy their food. Even though texts are usually silent about daily life, it is possible to describe some aspects of Assyrian society and the daily occupations of its members.

\section{Ashur and Kaniš}

The Old Assyrian city of Ashur occupied an area of about 55 hectares and probably housed between 7,000 and 10,000 inhabitants. But Assyrians were very mobile, often traveling to Anatolia (see Figure 4.1) and even staying there for extended periods of time. Archives unearthed in Kaniš's lower town indicate the presence of large numbers of Assyrians during the 19th and 18th centuries BCE. The city of Kaniš comprised between 170 and 230 hectares and was inhabited by some 25,000 or 30,000 people. Some 3,000 to 3,500 of them, their majority from Ashur, were living in the lower town commercial district, of which ca. 9 hectares have been unearthed so far (Barjamovic 2014; Hertel 2014).

Because Ashur was a trading center at the junction of important roads, many foreign merchants visited the city. Elamites exchanged tin for gold there. Babylonians from southern Mesopotamia sold their textiles in Ashur. People from upper Mesopotamia probably traveled to Ashur as well. Both in the city and abroad, Assyrian merchants interacted with foreigners on a regular basis. They identified them by means of their ethnicity and the languages they spoke, as described in a verdict: "Assyrians can sell gold among each other but, in accordance with the words of the stele, no Assyrian whosoever shall give gold to an Akkadian, Amorite, or Subaraean" (Michel 2001: no. 2; Veenhof 1995a: 1731). "Akkadian” was the name given to the Babylonian population; the "Amorites" lived along the Euphrates River west of the upper Jezira; and "Subareans" were the Hurrians who settled north of Ashur along the Tigris River.

In Anatolia, beyond the Euphrates River, the Assyrians referred to the local people with the word $n u \bar{a}$ 'um, which encompassed all of the Anatolians of Kaniš, as opposed to the Assyrians, who were called tamkārum ("merchant," see Edzard 1989). The personal names of the local population of Kaniš show that there were different ethnic groups: Hattians, Luwians, Hittites, and Hurrians (Garelli 1963: 127-68; Goedegebuure 2008; Wilhelm 2008). There were also merchants from Upper Syria who regularly visited Kaniš, from Ebla, for example. All of these people traded with each other and had no real communication problems. After one or two generations, Assyrian merchants had developed links with the local society that went beyond strictly commercial transactions (Dercksen 2002, 2007a; Michel 2010a, 201 la, 2014b; Ulshöfer 2000; Veenhof 1982a).

Old Assyrian society was divided into two main groups: the free citizens, who were called "men" (awīlum) or "sons of Ashur" (DUMU Ǎ̌šr), and "slaves" (wardum, amtum). There was no specific distinction between the Assyrian citizens, but according to their rank, age, and wealth, they were considered either as "big" (GAL, rabi) or "small" (TUR, saber) members of the assemblies of Ashur and Kaniš (Hecker 2003). Legally, there was also no distinction between women and men, who had more or less the same rights (Michel, forthcoming; Veenhof 2003b). 


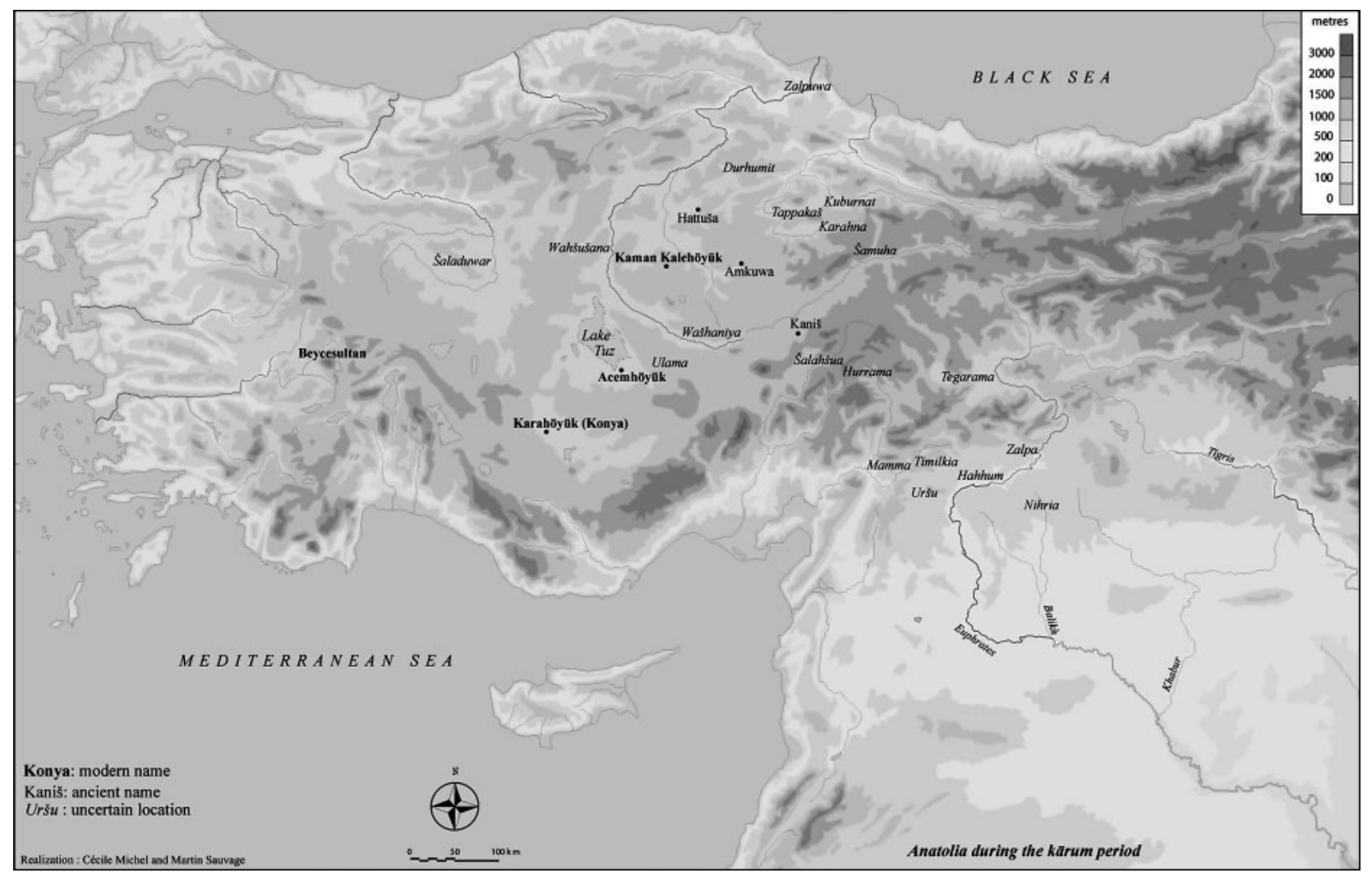

Figure 4.1 Anatolia during the Old Assyrian period. Source: Reproduced with permission of Cécile Michel and Martin Sauvage. 
The great majority of Ashur's inhabitants mentioned in the Old Assyrian archives from Kanis participated in the long distance trade: the king and his family, the high dignitaries, the eponyms and other officials, priests and temples, etc. (Michel 2015b). Some merchants built large fortunes, which also benefited the city-state - Ashur's City Hall raised taxes on caravans leaving or arriving in the city.

The king and the priests entrusted goods to a few important dealers in order to earn profits from the sale of their tin and textiles in Anatolia (Larsen 1976: 129-246; Michel 2015a). The eponyms, chosen from the important families of Ashur, were among the main traders in Ashur - some of them were active in Anatolia before or after their years of tenure (Dercksen 2004b; Kryszat 2004; Michel 1991; Veenhof 2003). Many occupations were linked to trade and caravan enterprises: bankers, bakers, traders, agents, employees (subārum), porters, guides or escorts, donkey drivers (sāridum), who were paid with salaries, and harnessers (kassārum), who were paid with operating capital; these latter two groups are well documented in hiring contracts (Larsen 1967; Michel 2001: 171-233; Veenhof 1994b).

In Kanišs, during the level II period, Assyrians were living in the lower town together with Anatolians, who participated in commercial activities as well. Initially, Anatolians were often indebted to the Assyrians. Later, through their implication in the trade and via mixed marriages, some Anatolians became increasingly wealthy and possessed some of the largest houses in the lower town (Michel 2011b). During the subsequent level Ib phase, commercial treaties distinguished the Assyrians who were involved in the caravan trade with Ashur ( $\bar{a} l i k \bar{u} \dot{s} a$ barrān ălim) from those who were living in the lower town (wašbūtum). The first group profited from the international trade and visited Ashur regularly, while the second group devoted all of its time to the intra-Anatolian trade and, subsequently, lost contact with Ashur. They were less wealthy, often even indebted to Anatolians and, as a consequence, specific clauses were created to protect them and their houses in the kārum, the "merchant's harbor" (Barjamovic, Hertel, and Larsen 2012; Günbattı 2004; Michel 2011a, 2011b, 2014a; Veenhof 2008: 147-82).

\section{Slaves}

In Ashur and Kaniš, the possession of several slaves was considered a sign of wealth, like the possession of a house (Veenhof 2011b). Slaves appear in sale contracts, last wills, and divisions of inheritance; they could be referred to collectively as subrum (Michel 2008b; Veenhof 2008: 110-11). Male slaves (wardum) and female slaves (amtum, which can also be translated as "second wife") cost an average of 30 and 20 shekels of silver, respectively. Anatolian slaves were usually less expensive (Kienast 1984: 28). Slave sale contracts served as title deeds. Wealthy merchants could afford and support an entire domestic staff. Women possessed their own slaves, whom they would acquire through their dowry or by purchase. Among the slaves they inherited, men could receive female slaves with whom they had sexual relations (EL 287). Some slaves belonged to institutions, such as the Ashur City Hall (Kt 93/k 76:32) and the Ashur palace (KTS 1 55b:3-4).

Female slaves had to clean the house, prepare the meals, and help raise the children. They even could procreate on behalf of their infertile owners (Michel 2006b). Some of the male slaves were employed in the long-distance trade, hired as caravan personnel. A slave could be sold in order to pay a debt: an Assyrian woman bought back a slave that had been sold by her daughter-in-law in order to pay the export tax her husband owed to the City Hall of Ashur (Michel 2001: 
no. 306). But a slave could also be seized by a creditor or by the authorities as security for a debt: "The eponym troubles me and he keeps seizing my slave-girls as security" (Michel 2001: no. 315). There were many debt slaves, especially among the Anatolians, who could often not pay the high interest rates imposed by the Assyrians. But there were also Assyrian children in Ashur who were given as pledge (erubbātum) for their fathers' debts, detained by the creditor, and sometimes sold to repay the debt after the deadline had expired (Michel 2003a; Veenhof 2001; and below "Housewives, children, and education"). From letters, we learn that Assyrians could be detained as hostages by the local authorities and released with a heavy ransom (Günbattı 2001; Michel and Garelli 1996; Michel 2008e, 2014a).

\section{The Assyrian Family}

The family formed the basic unit of Mesopotamian society and thus occupies an important place in the written documentation, especially in law codes. Since no written laws have been recovered in Ashur or Kaniš, Old Assyrian family law must be reconstructed on the basis of contracts, court decisions, and letters. The letters provide primarily data on women who were alone because their husbands were away, because they were widows, or because they were consecrated to a divinity. Married women living with their husbands in Ashur or Kaniš did not need to write, or wrote only very few letters to other members of their families (Michel 2009d, forthcoming).

Contrary to the widespread belief that in Mesopotamia's patriarchal society women were permanently under the men's control, in the Old Assyrian sources they appear to be equal to men in many areas: men and women were both allowed to initiate divorce proceedings and had to pay identical fines, boys and girls could both inherit property, men and women participated in trade, lent money, bought and sold houses and slaves, or made their last wills (Michel, forthcoming; Veenhof 1995a, 2008a).

The following discussion focuses on the Assyrian family but also considers Anatolians in case they had family ties with Assyrians (Michel 2008c).

\section{Marriage, divorce, and widowhood}

About forty Old Assyrian contracts, as well as a dozen legal texts, deal with marriage or divorce. These documents predominantly concern Assyrians, but also Anatolians, and reflect different traditions (Kienast 2015; Michel 2006b, forthcoming chapter 1; Rems 1996; Veenhof 1997b). Some letters provide data about the marriage ceremony and the status of wives. They also allow prosopographic reconstructions, which help us understand the various family situations.

Written marriage contracts may have been drafted only in particular cases, and they do not seem to be standardized. The agreement was made between the parents of the bride and the groom or his family. The marriage was planned so that it would take place when the girl reached adulthood:

Ahu-waqar and Zupa seized us (as arbitrators) and Ahu-waqar (said) to Zupa as follows: "My sister has grown up! Come here and marry my sister in Kaniš." Zupa (answered) as follows: "Let her wait!" Then Ahu-waqar (said): "In Kaniš, you had the verdict of the kārum. You are far away! 
How long should my sister keep waiting?” Then Zupa (said): “Go ahead and give your sister to a husband of your choice.” (Kt i/k 120 published by Balkan 1986; Michel, forthcoming: no. 6)

Marriage contracts document men taking ( $a \bar{a} \bar{a} z u m)$ women as wives. Marriage gifts (Veenhof 1998: 190, n. 66) are rarely mentioned in the Old Assyrian contracts, but a few letters state that if no gifts were exchanged the betrothal could be broken off (Figure 4.2):

Pilah-Ištar seized us (as arbitrators) against Amur-Ištar, and Pilah-Ištar (said to him) as follows: "You gave your word to my father. Come and marry your wife!" Amur-Ištar (answered) as follows: "I indeed gave my word to your father, but as my in-laws you (pl.) did not give me a belt for my waist, nor did you invite my brothers. Time passed and I have grown old, so I have married another girl from Ashur. Thus, I will not marry your sister." (Kt 88/k 625 published by Sever 1992b: 670; Michel, forthcoming: no. 7)

The dowry given to the bride when she left her father's house belonged to her and was later inherited by her children. During the marriage ceremony, the groom gave the bride-price (simum) to the parents of the bride; a banquet took place and the bride was covered with a veil. But this symbolic act did not mean that married women had to wear a veil. After the ceremony, the woman left her family house for the house of her husband, who had to provide her with food and garments on a regular basis.

As a rule, marriage was monogamous. Some marriage contracts state explicitly that the groom promised not to take another wife. If after two or three years of marriage the wife had not given birth to any children, the husband was allowed to buy a slave (who could also be chosen by the wife) in order to produce heirs. This woman, however, remained a slave and never gained the status of second wife (Michel 2006b).

The particular situation of the Assyrian merchant, who was always far away from his homeland and settled in Anatolia for long periods of time, allowed him to take a second wife there:

Puzur-Ištar married as an amtum-wife Ištar-lamassi, daughter of Aššur-nada, and he can take her along with him to Burušhattum or to Hattum, wherever his journeys will (lead) him, but he must bring her back with him to Kaniš. If he divorces her, he shall pay 5 minas of silver. If it is she who divorces him, she shall pay him 5 minas of silver. Also he shall not marry another (wife) apart from his ašsatum-wife in the city of Ashur. (Prag I 490; Michel 2006b; forthcoming no. 23)

Hattum was the name of the area located inside the Kizll Irmak bend, and Burušhattum represented the most western Assyrian trading post. As stated in this contract, the second marriage had to respect two rules: the merchant could not marry two women with the same status - one had to be the ašsatum ("main wife") and the other the amtum ("second wife") - and he could not have two wives in the same area - one had to live in Ashur, the other in Anatolia. The main wife could be either Assyrian or Anatolian and she could live in either Ashur or Anatolia. So while the merchant was legally bigamous, he was not bigamous in practice since he never lived with both of his wives at the same time (Kienast 2008; Michel 2006 b). Even if he travelled on a regular basis in Anatolia, he was not allowed to take a third wife in another trading post, but had to take the wife he married in Kaniš with him during all his travels, especially if she was Assyrian (Michel 2008c). The husband had to ensure that each of his spouses had a house to live in, as well as food and wood for their household. 


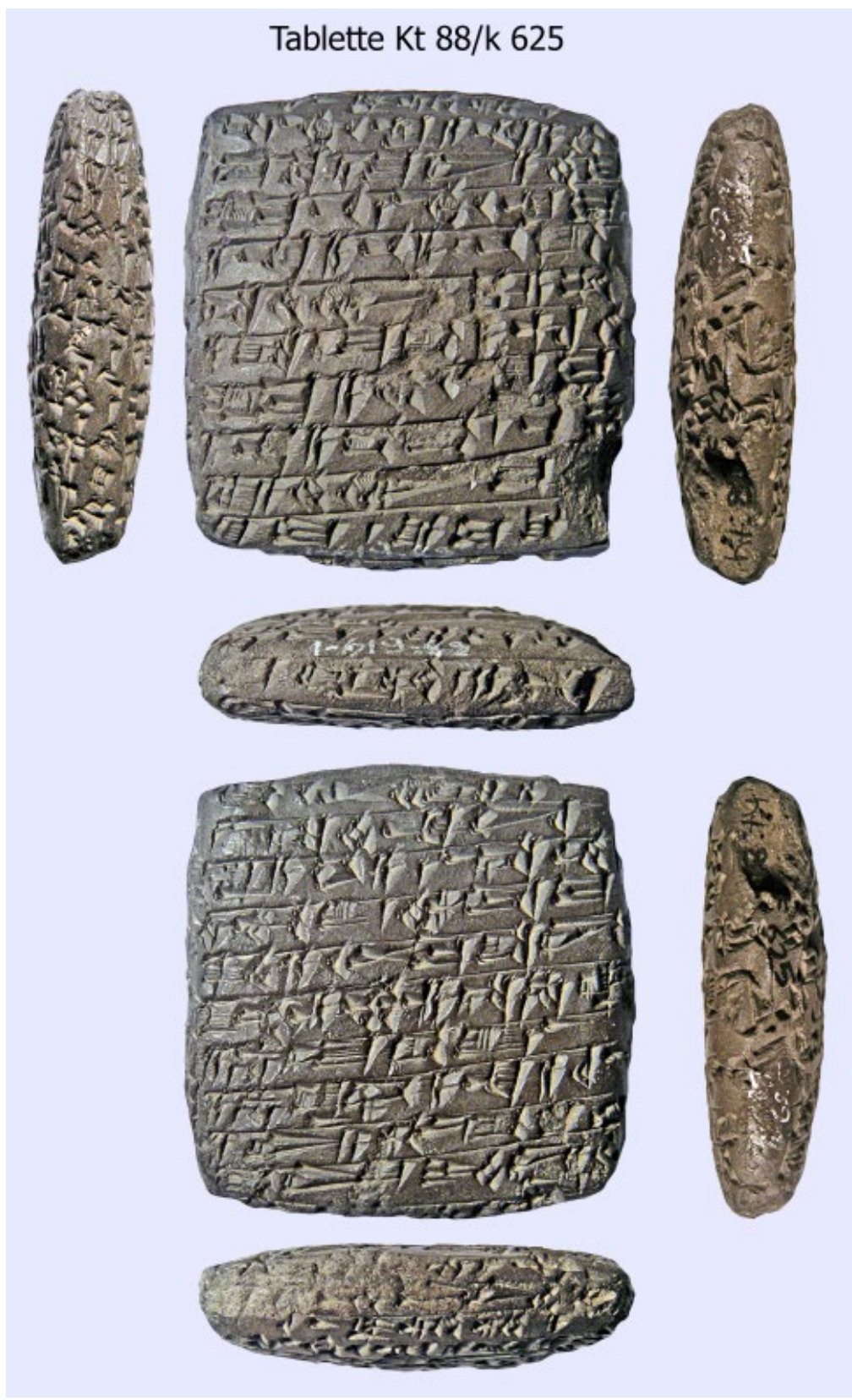

Figure 4.2 The Old Assyrian letter Kt 88/k 625. Ankara, Anadolu Medeniyetleri Müzesi. Source: Photo Cécile Michel, reproduced with the permission of the archaeological mission of Kültepe.

One can thus easily imagine that only wealthy merchants could financially support two wives and households at the same time.

From the letters, it seems that both wives had the same rights concerning their husband, but it may have been that the children of the second wife had fewer rights regarding the inheritance of their father than those of the first wife. 
This special situation left married women to manage their households alone for extended periods of time. The Assyrian wife was in Ashur during her husband's Anatolian career, raising her children, while the Anatolian wife could live with her husband as long as he was staying in Asia Minor but was left alone when her husband retired and went back to Ashur (Michel, forthcoming: chapter 1).

Some marriage contracts deal with the case of a possible divorce. Husband and wife could both initiate a divorce, and the fines, often high (up to 5 minas of silver, ca. 2.5 kilograms), were the same for both parties. These gender-neutral regulations, very different from the situation in Babylonia, may have been influenced by the Anatolian tradition, in which both spouses had equal rights and shared common property (Michel 2008c). A large majority of divorces were consensual and resulted from private agreements made in the presence of witnesses. If the wife behaved badly, the husband was allowed to repudiate her without paying any compensation: he could strip her of her possessions and chase her away. On the other hand, if a man developed a loathing for his wife, he could send her back to her father's home but had to pay her compensation (Donbaz 2003; Kt 94/k 141; Michel, forthcoming no. 31). Divorced men and women could remarry as they wished:

\begin{abstract}
Šakriušwe (was) the wife of Aššur-taklaku; husband and wife divorced. One will not raise claim against another with respect to anything. They will not raise claim regarding her bride price. Šakriušwe will go to (the husband) of her choice, either an Anatolian or an Assyrian, and Aššur-taklaku will marry the wife of his choice. (Kt n/k 1414; Sever 1992b: 668; Michel, forthcoming no. 38)
\end{abstract}

Many examples deal with the divorce of an Assyrian from his Anatolian wife. This happened regularly when the Assyrian merchant decided to go back to Ashur and remained there. He thus had to first make a divorce agreement with his local wife and to make a decision about their children. The husband had to pay divorce money and he could decide to take his children with him, or to take only the boys and older girls after having paid for their upbringing and their food (Michel 2008c).

When a father died, his children inherited his goods and had to take care of their mother; if there was no child, the widow could remarry and keep her dowry. When a mother died, her children shared her dowry; if there was no descendant, the dowry was given back to the family of the deceased wife (Veenhof 2008a). The widow could also inherit from her husband if he had written a last will which gave her rights over the house and the capital:

Agua drew up his will as follows: The house in Ashur is the one of my wife. Concerning the silver, she will share it with my children. Concerning the silver, her inheritance share, she is (like) father and mother. House and silver, her inheritance, as well as everything that she (already) possesses, (will be later) the property of Šu-Belum. (Albayrak 2000; Michel 2000b, forthcoming no. 54)

But after her death, everything a wife inherited from her husband belonged to their eldest son, who was in charge of his parents' funerals and the worship of his ancestors. A widow was free to remarry either an Assyrian or an Anatolian: there are several examples of Assyrian widows married to Anatolians (Kryszat 2007a; Veenhof 2008a; Michel, forthcoming). 


\section{Housewives, children, and education}

In Ashur, many women lived alone, waiting for their husbands to return. The youngest wives had to live with their in-laws, and cohabitation was not always successful (Michel 2001: no. 320 , forthcoming no. 146). Other wives had to not only raise their children alone and carry out the daily work of women, but also, as the heads of their households, provide clothing and food to children and servants, repair the house, and so forth (Michel, forthcoming: chapter 3 ). To deal with such matters, they sent many letters to their husbands in Anatolia.

We know very little about the age of puberty, the age of marriage, or the number of children per woman, but the reconstruction of the genealogies of some well-known Assyrian families gives us at least a vague idea of the average number of children who became adults. Taking into account that girls are not always mentioned (Michel 2015c), there might have been an average of three to six children per woman who reached adulthood. The most prosperous couples had more children than others: they earned enough to raise the children and to leave them property after their death. The children had to care for their aging parents, to pay for their burials, and to provide their spirits and dead bodies with what they needed (Michel 2008f; Veenhof 1998, 2008a, 2014a). In poor families, children could be pledged, or even sold, for a debt (see the sub-section on slaves).

Maternity is usually not documented in private archives but was the subject of medical and magic texts. Five of the ten Old Assyrian incantations found in Kaniš were intended to help a woman in labor, to cure a newborn baby of jaundice, and to chase away the evil demoness Lamaštu, who attacked pregnant women and babies (Barjamovic 2015; Kouwenberg and Fincke 2013; Michel 1997e, 2004b; von Soden 1956). One text identifies a woman not by her name but by her profession as a midwife ( $\check{s} a b s \bar{u} t u m$, TC 3 219:9).

In the letters they wrote to their husbands, women revealed their anxieties about raising and educating their children (serrum, subrum). The merchants abroad wrote to their wives in order to get news of their progeny (Michel 1997d, forthcoming; Veenhof 2008: 106).

Children were raised in a feminine environment, since the eldest sons followed their fathers abroad. Some wealthy families could hire a wet nurse (mušéniqtum), who received a salary. When a mother died, sometimes in childbirth, her children were entrusted to family members, such as uncles or grandparents. When Aššur-nada settled in Anatolia, he already had a son and daughters in Ashur, who were raised by their paternal grandfather, Aššur-idi, because their mother had died quite young. Even though Aššur-idi received a pension (tarbitum) from his son, he complained that, despite all the time and money he was dedicating to his grandchildren, they did not respect him:

I have raised your son, but he said to me: "You are not my father." He got up and left. Also I have raised your daughters, but they said: "You are not our father." Three days later, they got up and left to go to you, so let me know what you think. (Larsen 2002: no. 22; Michel 2001: no. 254)

In leaving their grandfather, the children used the classical formulas for breaking an adoption contract: they refused their grandfather's tutelage. There are very few examples of adoptions because such contracts were kept in family archives in Ashur. The adopted child, who could have been a slave, inherited from his adoptive father.

The father had legal authority over his children and the right to decide whether to marry off or consecrate his daughters. The younger children were raised by their mother, who was also in charge of their moral and religious education. Boys could go to a master in order to 
learn how to read and write (Michel 2008a). When they became teenagers, they followed their fathers to Anatolia and learned the basics of the trade. Girls stayed with their mother, helped her with her daily tasks, and learned how to spin and weave. They contributed to the domestic production of textiles (Michel 2006d).

\section{Consecrated women}

In several Old Assyrian families, parents consecrated their eldest daughter to a god, presumably Assur. It was a religious act of gratitude to the god for their flourishing trade and a way to confirm their social position. In fact, some of the consecrated girls belonged to the richest families of Ashur. Consecrated women (gubabtum, NIN.DINGIR) lived independently in Ashur, possibly near the temple. Their religious pursuits are almost never documented in the tablets found in Kaniš (Dercksen 2015, 53-4), but we have letters and legal texts illustrating their status and economic activities (Michel 2009c). A girl was consecrated before being old enough to get married, as we learn from a letter sent by an Assyrian woman to her husband: "(Our) young (daughter) has grown up very much; come and put her under the protection of the god Assur, and seize the foot of your god" (Michel 2001: no. 307, forthcoming no. 166). The woman succeeded in persuading her husband, since we learn that her daughter did in fact become a gubabtum. Once consecrated to the god, a woman could not get married but was economically independent. She had her own capital with which she participated in the trading activities of her family, investing in the long-distance trade and lending money. She was the owner of the house in which she lived and, like her brothers, could inherit from her father. She was even free to travel and settle in a foreign land, where she could own a house (Michel 2009c). The letters sent by consecrated women to Anatolia show that they were involved in many important family decisions. One of them gave advice to her sister, who was traveling abroad and leaving husband and child in Ashur; she tried to save her sister's marriage, which was in danger (Veenhof 2007a). Other categories of consecrated women, such as the qadistum, could marry, but were not allowed to have children (Michel 2006b, 2009c, forthcoming: chapter 5).

\section{Succession}

Since there was no general rule concerning inheritance, Assyrians usually wrote last wills. In these documents, they took care to protect the interests of their wives and daughters. In the case of a sudden death, the lack of a written testament was the source of many problems. According to the very few testaments recovered (most of them were kept in Ashur), and according to the verdicts of trials dealing with inheritance, the Assyrian tradition used to give the eldest son a more important share than the share reserved for other children (Michel 1997d, forthcoming: chapter 2; Veenhof 2011a). His inheritance share often included the main house, where he had to take care of his mother if she was still alive. Another possibility was that the house was given to the widow in usufruct and was handed over to the eldest son at a later time.

Sons had to pay the debts of their fathers before sharing his goods with their consecrated sisters. The other daughters usually received their share in the form of a dowry. If a father died before marrying off his daughters, their brothers had to arrange and finance their marriages 
with their inheritance shares. Unlike sons, daughters were not responsible for their fathers' debts (Michel 2003a, forthcoming).

Consecrated women were always mentioned in last wills and could be the first among the children to inherit (Hecker 2004a; 2004b; Michel 2009c). They received silver, loan contracts, servants, and sometimes an annual allocation: "My sons will pay my backers and of the silver left belonging to me, (my daughter) Ab-šalim will first take $1 / 3$ mina of gold, 1 mina of silver, and a maid" (Kt o/k 196c; Albayrak 2000; Michel 2000b; forthcoming no. 54).

After the death of a mother, her children normally inherited her dowry and goods, but some widows preferred to write their last wills in order to divide their property as they wished. Lamassatum, the wife of Elamma, left silver cups and toggle pins, several silver loan contracts, textiles, slaves, and slave-girls. All of her belongings were entrusted to her representatives and sent to Ashur where "my daughter, the consecrated girl, and my sons will act in accordance with the testamentary dispositions applying to them" (Kt 91/k 421; Veenhof 2011a). A dozen documents concern the burial and succession of Ištar-lamassi, first the widow of the Assyrian Kunilum, with whom she had three children, and then the widow of the Anatolian Lulu. She wrote her last will in order to split her property between her two sons and her daughter, who even received a seal, which was usually reserved for the eldest son:

(Of) the 57 shekels of silver that are available, Ilia will receive 37 shekels, Ilabrat-bani will receive 20 shekels, (and) they will send to my daughter, the gubabtum, $21 / 4$ shekels of gold and $7 \mathrm{l} / 2$ shekels of silver and a seal. (Kt 9l/k 453; Veenhof 2008a: 103, 106).

After both brothers died soon after their mother's death, a great deal of money was spent for the burial of Ištar-lamassi's second husband and for her two sons' burials. The daughter, Šmat-Ištar, was the only child left and inherited the rest of the fortune.

\section{Elderly people and ancestors}

Care of the elderly was the responsibility of the family, primarily of the sons, which may explain why some merchants went back to Ashur to take care of their aging parents and to bury them (Veenhof 1998, 2014). Children inherited from their father and had to take care of their mother; sometimes, she could stay in the family house even if the building had to be sold (Michel, forthcoming no. 51-52). In an adoption contract dated to the later period, Level $\mathrm{Ib}$, the parents adopted an adult slave: he could inherit against the promise to respect his adoptive parents, to take care of them, and to later bury them and perform the cult of the dead (Veenhof 1982c).

When a member of the family died, the family organized and paid for the funeral. The body was buried in a grave (quburum) during a ceremony (bikitum), and there was a period of mourning (Michel 2008f; Veenhof 2008a). It was believed that after their death, ancestors lived on as spirits $(e t e m m \bar{u})$. They dwelled in the Underworld with all the other ancestors of the family and could appear to their descendants as ghosts in their dreams. Altogether, the living members of the family honored the ancestors and maintained relationships with them by means of prayers and offerings. To make this obligation easier to fulfill, deceased family members were buried under the floor of the house. Because of this tradition, it was very difficult for descendants to sell the family house (Michel 2008f; 2009b). 
In Kaniš's lower town, the cist graves that were dug under the houses of level Ib disturbed the rooms from level II. Some of the graves contained ceramics, various objects, and jewels (Emre 2008; Üstündağ 2014). Some graves of wealthy Old Assyrian merchants were also excavated in Ashur. They contained very valuable funerary offerings: bronze vessels and weapons, jewelry made of gold and precious stones, cylinder seals, as well as figurines and golden leaves that were used in the afterlife rituals (Haller 1954; Hockmann 2010).

The eldest son, who inherited the family house, was in charge of the rituals performed for the deceased family members. But if he was in Anatolia for trade purposes, and his sisters or wife lived in his house in Ashur, a problem arose: because they could not perform the cult of the dead, they received warnings from the spirits and were exposed to the anger of the ghosts, who were furious that their heirs had abandoned them. In a letter sent to their brother and uncle, two women complained that they were being treated poorly by demons and spirits of the dead: "Here Belatum is ill because of the silver of the $i k r i b \bar{u}$-votive offerings. We are mistreated by demons and spirits of the dead" (Michel 2001: no. 323). The women were eager to see their husbands and brothers retire and come back to Ashur (Michel 2008f, forthcoming: chapter 5).

\section{Economy and Daily Life}

The written documentation from the Old Assyrian period focuses on the Assyrian trade between Ashur and Kaniš. Merchants from Ashur brought tin, which had been imported from the east, and textiles, locally produced or acquired from Babylonians, on a six-week journey to Kanišs, and sold them there. On the way back, they brought gold and silver to Ashur.

References to daily life are usually rare in the documents. Nevertheless, the many private letters from Kaniš do provide some data about topics such as textile production, several other crafts and occupations, and the markets and shops where people could buy the food that they needed daily. Some letters are quite emotive (Larsen 2001). Assyrian-owned houses and furniture are mentioned as well and have been found in the excavations that have been undertaken in Kanišs's lower town. Several documents allude to religious practices and Assyrian gods.

\section{Family enterprises and other trade networks}

As mentioned above, the long-distance trade was to a large extent a family affair. Each family member had specific tasks to perform within the trade system. The family enterprises, based in Ashur, had representatives in several Anatolian trading posts. Family ties formed the basis of many professional relationships (Dercksen 1996: 90-161; Ichisar 1981; Larsen 1982a, 2002, 2010; Michel 1991, 2005).

That business relationships were derived from family affiliation is also reflected in the vocabulary: the "house," betum, could refer to the enterprise, the "father," abum, was the boss, the "brother," abum, was a partner, and younger members of the family, s $\bar{u} h \bar{a} \bar{r} \bar{u}$, were employees (Hertel 2015; Veenhof 2014a). Often, the father, who was at the head of the family enterprise, lived in Ashur and did not travel to Anatolia. He was the one who made important decisions on behalf of the family enterprise. He gathered capital to buy tin, textiles, 
and donkeys, and he organized the caravans and shared the profits earned; his eldest son, usually settled in Kaniš, managed the Anatolian branch of the family enterprise. He received the deliveries of merchandise that arrived from Ashur and organized its sale in Kaniš or entrusted it to agents responsible for its sale in other trading posts within the Anatolian plateau. The other sons helped with selling tin and textiles in Anatolia, transporting the goods between the main Anatolian localities, or traveling between Ashur and Kaniš with the caravans. Some of them represented the family enterprise in other Anatolian centers, where they settled more or less permanently (Michel 1991: 140-2, 2001: 359-418). Wives and daughters living in Ashur participated in the family trade by weaving high-quality textiles for long-distance trade. Often left alone in Ashur, they represented the interests of their male relatives and were also involved in some financial operations (Michel, forthcoming: chapter 5 ).

In Kanišs, after one or two generations, mixed marriages between Assyrians and Anatolians increased. These marriages joined Anatolians to Assyrian families, thus enlarging the network of professional relationships (Michel 2010a; Veenhof 1982a). After the death of the father (and boss) in Ashur, an uncle or the eldest son could take over the management of the family enterprise. But the uncle or son in question could also decide to start his own enterprise with a new organization (Larsen 2007). The Old Assyrian archives, which predominantly document two generations of families from the point of view of the family members settled in Kaniš, reveal that brothers sometimes had few business contacts; this is the case with the sons of Issu-arik (whose archives were excavated in 1994; Larsen 2010), and with Elamma and Ali-ahum, the sons of Iddin-Suen, whose archives were unearthed in 1991 and 1993 (studied by K. R. Veenhof and C. Michel).

An Assyrian's social position and reputation was determined by the wealth of his family enterprise, even though the capital was clearly owned individually (Larsen 2007). This also applies to married couples, with husband and wife managing their own finances (Michel 2006 d, forthcoming chapter 4 ). The extended family served as a network of professional relationships in which property and responsibility were strictly individualized; there was no common fund. This explains, for example, why there were loan contracts with interest between members of the same family.

Families could interact with other kinds of networks created to engage in long-distance trade: an example is the system of joint-stock partnerships in which several investors could put their capital together in order to finance commerce that was carried out by an agent for a dozen years or longer (Dercksen 1999; Larsen 1977, 2007; Michel 2001, 2005; Veenhof 1997a, 1999a). Junior members of the family could belong to a family enterprise headed by their fathers and, at the same time, to a joint-stock partnership under the authority of investors who had no family ties with them. The line between family ties and commercial networks is often hard to draw, which makes it difficult to understand what exactly was hidden behind the well-attested expression bèt abini "the house of our father" (Hertel 2015; Larsen 2007; Veenhof 2014a).

\section{Loans}

Loan contracts between Assyrians and Anatolians, or within the Assyrian community, were frequent. Some debt-notes resulted from the sale on credit of merchandise and had only a default interest (Veenhof 1999a; Michel 2013b). Some employees were paid with interestfree working capital (be'ulātum) instead of a salary. 


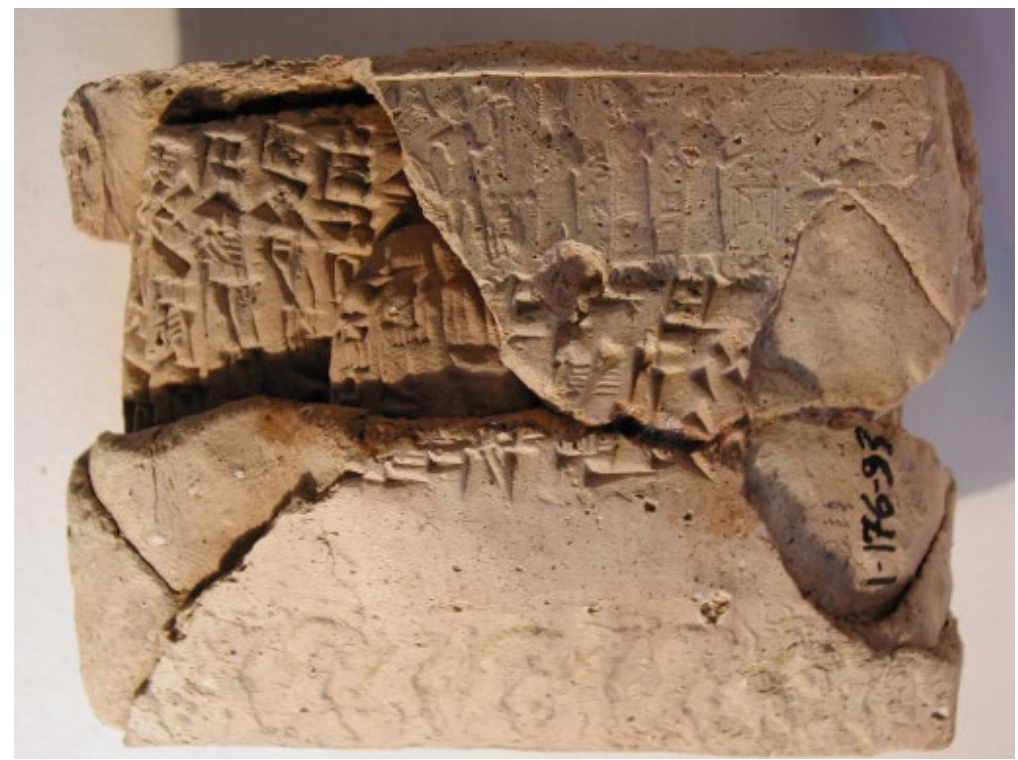

Figure 4.3 An Old Assyrian letter comprising a main tablet and a small second one preserved together in their sealed envelope. Kt 93/k 211, Ankara, Anadolu Medeniyetleri Müzesi. Source: Photo Cécile Michel, reproduced with the permission of the archaeological mission of Kültepe.

Non-commercial loans with interest between individuals consisted of small quantities of silver or cereals. Silver could be borrowed with interest from the house of a tamkārum. For the Assyrians, the interest fixed by the kārum office amounted to 30 percent per year; it was even higher for the Anatolians. The creditor could ask for guaranties: a guarantor, the joint responsibility of debtors, or a surety (such as members of the family, the house, or other goods). If a guarantor had to borrow silver in order to pay the loan, the creditor could impose an interest on top of the established interest of the debtor. Loan contracts were for short periods of time, generally shorter than a year.

When a debt was repaid, the creditor gave the loan tablet back to the debtor and the contract was cancelled by breaking the envelope or by giving the debtor a receipt (see Figure 4.3) (Dercksen 1999; Michel 1995, 2003a; Veenhof 2001, 2003b).

\section{Textile production and businesswomen}

The long-distance trade was based in Ashur, where the families of the merchants were settled. Ashur was the transit city for the tin and textile trade, but many households also produced textiles locally. All of the women in the household weaved textiles, but not only to dress their family: most of the textiles they produced were exported to Anatolia (Michel 2006d, forthcoming: chapter 4; Michel and Veenhof 2010; Veenhof 1972). Not always could they satisfy the demand for textiles:

You should not get angry because I did not send you the textiles about which you wrote. As our little girl has grown up, I had to make a pair of heavy textiles for the wagon. Moreover, I made 
(some) for the staff of the household and for the children; this is why I did not manage to send you textiles. (Michel 2001: no. 307; forthcoming: no. 166)

The total production by the women who belonged to the same household would amount to some twenty-five textiles a year: this was not enough for the thousands of textiles exported each year. Thus, the Assyrians also bought textiles from Babylonians. There is no reference to institutional textile production in Ashur.

Women bought the wool nearby, which came from sheep that grazed in Suhum and were brought to Ashur to be plucked. Surbu'itum wool, which came from animals that were bred in the Hamrin Mountains, was the best for weaving the kutānum textiles that were exported to the west (Dercksen 2004a: 16, n. 32; Michel 2014c; Michel and Veenhof 2010: 221). But more so than the quality of the wool, it was the technical skill of the Assyrian women that mattered. They were even able to copy various techniques used in other cities, and their products were valued by the men of the family, who frequented the Anatolian markets and knew very well the nature of the demand:

As for the thin textile you sent me, you must make such ones and send (them) to me with Aššr-idi, and I will send you $1 / 2$ mina of silver (apiece). One must strike the one side of the textile, and not pluck it, its wrap should be close. Add, per piece, one pound of wool more than you used for the previous textile you sent me, but they must remain thin! Let them strike its second side only slightly. If it proves still to be hairy let one pluck it like a kutānum. As for the Abarnian textile you sent me, such a one you must not send me again. If you make (one), make (it) like the one I dressed myself in there. If you do not manage (to make) thin textiles, I hear that there are plenty for sale over there, buy (them) and send them to me. A finished textile that you make must be nine cubits long and eight cubits wide $(4.5 \times 4$ meters $)$ (Michel 2001: $\mathrm{n}^{\circ}$ 318, forthcoming: no. 162; Michel and Veenhof 2010: 250-2; Wisti Lassen 2010: 274-6).

Once the textiles were finished and went through the cleaner, the women organized the textiles' transport to Anatolia, entrusting them to male members of their family who traveled regularly between Ashur and Kaniš or paying transporters who could add a few units to their loads. In exchange for the sale of their textiles, the women received gold and silver, sometimes in the form of jewelry, which they sold on behalf of their households or invested in commercial transactions and in loans with interest. The more textiles they sent, and the better their quality, the higher the price they received. The regular production of textiles ensured the women an income. Besides the management of their personal funds, women acted as representatives for their husbands and brothers. They acted as true businesswomen (Michel 2006d; forthcoming: chapter 4).

\section{Craftsmen and other professionals}

Aside from information on the women weaving at home, the Old Assyrian documents include very little data on craftsmen or other professions in Ashur, and occupational designations concerning Kaniš refer predominantly to Anatolians. However, it is possible to give a list of attested occupations, even if we know almost nothing about the social status of the individuals who held them (Michel 2015b). 
Besides the many activities linked to the political, legal, and economic administration of the state (kings, eponyms, officials of the City Hall and of the $\bar{b} \bar{t} t k \bar{a} r i m$, scribes, stewards, judges, attorneys, messengers, and different functionaries; see Dercksen 2004a), to religion (see below, "Religion"), or to the international trade, both in Ashur and Kaniš (merchants, agents, transporters, donkey drivers, harnessers, guides, escorts, and even smugglers), the texts cite few professions. Several Ashur eponyms are mentioned with their professions: Aššur-imitti the boatman, Puzur-Aššur the ghee trader (or: the one who supplies the palace with ghee), and Amaya, the one in charge of the weapons (or: an arms dealer) (Kryszat 2004; Veenhof 2003). Indirect references also appear, such as "the house of the carpenter" (Michel 2001: no. 345). It is likely that other specialized craftsmen, such as bleachers, rope makers, and leather-workers, were also active in Ashur (Dercksen 2004a: 255-85).

In Kaniš, apart from the numerous functionaries working for the local palace, there were various specialized Anatolian craftsmen: house builders, carpenters, leather-workers, textile cleaners, potters, gardeners, shepherds, oil traders, salt traders, female millers, and wetnurses. In Hattuš, there is a reference to a female tavern keeper (KBo 9 10:4). But we also find Assyrians who were not merchants. Among these are "interpreters" (targumannum), “metal workers" (nappāhum, Dercksen 1996: 71-6; Sturm 2001), a “tavern keeper” (sābium), a "confectioner" (kakardinnum), a "barber" (gallābum), who was sold as a slave, and a "weaver" (ušparum; Michel 2001: 561-77, 2015b; Veenhof 2008: 118).

\section{Market and shops}

Besides the warehouses in Ashur where one could buy tin and textiles, there were "markets" (mahīrum) or stalls and street shops for local products covering basic needs and, perhaps, wool to produce textiles (RIMA 1, 49:62-4). These would not necessarily have left archaeological traces, since they could have been in open-air places. In Ashur, women had to buy barley to feed their households with the silver they earned from their textile production:

It is the right season; take good care to send me, in exchange for my textiles, silver from what you happen to have at hand, so that I can buy 10 measures of barley. (Michel 2001: no. 344, forthcoming: no. 128)

The City Hall could sell barley and copper, as well as products that would be subsequently exported to Anatolia. A larger market might have existed near the city gate but it is not mentioned in the texts (Dercksen 2004a: 33-9).

In Kaniš, the "market" (mabirrum), presumably located on the citadel, was partly covered and controlled by the "chief of the market" ( rabi mabirim). It included shops or stalls where people could buy slaves, agricultural products, and animals from the surrounding villages, as well as different varieties of wheat and barley, wood, reeds, and cattle (Dercksen 2008a; Hecker 1997; Michel 2011a; Veenhof 2003c). The Assyrians who worked full time trading metals and textiles were totally dependent on these markets for products for their daily lives. Some of them, however, had Anatolian wives and were more fortunate since these women were also involved in agricultural tasks such as fieldwork and the breeding of oxen and pigs (Michel 2008c). 


\section{Metrology and means of payment}

In their many transactions, the Assyrians used a decimal system to count discrete objects, for example, textiles and bread. Products that were usually measured in units, such as cereals, were sold in "sacks" (naruqqum, ca. 1201.) and "jars" (karpatum, ca. 301.) of a standard capacity. Beer was measured in "jugs" (kirrum). Among the different metrological systems used by the merchants, the weight system dominated because of the nature of the traded goods, which were predominantly metals (Michel 2006a). Tin, gold, silver, and iron were measured according to the classical sexagesimal weight system in shekels, minas, and talents. In Anatolia, copper was weighed in hundreds of minas, in a system that ignored the talent, perhaps influenced by the local decimal system.

A tablet dated to the level Ib period gives a metrological correlation, indicating that 840 Anatolian minas equaled 760 Assyrian minas, which means that the Assyrian mina was 10 percent heavier than the Anatolian one (Kt u/k 3; Dercksen 1996: 87; Michel, in press).

The length system was occasionally used when measuring textiles in cubits (ammatum, ca. $1 / 2$ meter), and the subtum (perhaps equivalent to $36 \mathrm{~m}^{2}$ ) served to give the surface area of a building (Veenhof $2011 \mathrm{~b}$ ).

In Ashur, Assyrians probably paid gold for the tin they bought from the Elamites but paid silver to the Babylonians for the textiles they imported. They also used silver to buy houses, slaves, and large amounts of cereals, or to pay taxes to City Hall; loans were usually made in silver. It was exchanged in the form of rings or refined ingots broken in small pieces (sarrupum, Veenhof 2014b).

On the way to Anatolia, tin was used for current expenses, such as to pay the inns where caravans stopped and cover the toll when crossing borders. Tin circulated in the form of rings and small ingots (Dercksen 2005a; Veenhof 1972: 32-5). Silver and copper items were also used as small change.

In Anatolia, Assyrians were involved in the local trade in copper, a metal that, in the form of ingots, small pieces, or even old sickles, served to buy cheap goods such as food products (Dercksen 1996; Lehner 2014).

\section{Meals}

Letters written by women from Ashur mention the need to buy barley and to prepare beer bread for their husbands, but we know much more about the diet of Assyrians who were settled in Kaniš. Bread and beer represented the main food and drink products; water consumption was taken for granted and is thus never mentioned.

Cereals and products derived from them such as flour, porridge, and bread were the staple foods. Grains of wheat, barley, and spelt were crushed and ground to make flour, which was used to make two kinds of bread: bread made only with flour and water or sourdough bread. Sesame oil and animal fat, such as lard, were used for cooking but also for lighting or for washing. The diet also included vegetables, mainly leeks and onions, and fruits (nuts, grapes, and pomegranates). Herbs and spices, such as cumin, coriander, or mustard, were added to dishes, and people in Kaniš used salt from the Tuz Gölü both as a condiment and as a conservative. Honey, measured in jars, served as a preservative or as a sweetener (Dercksen 2008a, 2008b; Fairbairn 2014; Michel 1997a). 
Assyrians also ate meat (sheep, oxen, and pork) as well as fish and shrimp. The animals were often killed at home, or cuts of meat were bought and grilled. For their many travels, merchants could buy meat dishes, such as stew (Atici 2014; Dercksen 2008a; Lion, Michel, and Noël 2000; Michel 1997a, 2006c, 2014d).

Assyrians primarily drank beer, but they also appreciated wine, which was made from Cappadocian grapes. Brewing beer was a typically domestic activity: prepared at home by the women, it was made through the maceration and fermentation of barley, with malt and beer bread as the main constituents. In Ashur, malt was obtained from germinated barley grain while, in Anatolia, it was prepared with wheat grain. The beer bread was made of crushed barley. Each house had a stock of malt and beer bread ready to use for making beer. Beer and wine were served during private and public feasts, but some merchants had beer daily and would get drunk (Michel 2009a).

Meals were prepared by the women, who cooked in the metal vessels that they received as part of their dowry. In a letter sent to his fiancée, an Assyrian merchant mentions the duties of the wife, namely, serving her husband and cooking for him: "Please, the day you hear (the words of) my tablet there, turn to your father (so that he agrees), set out and come here with my servants. I am alone. There is no one who serves me nor to set the table for me" (Michel 1997a; forthcoming no. 3).

\section{Houses and furniture}

In Ashur and Kaniš, the Assyrian merchants bought, built, or extended their houses; sale contracts were used as title deeds (Kienast 1984) and redemption was possible for houses that had been sold as guarantees (Veenhof 1999b). The house was the building that accommodated people for the night but, more importantly, it represented the family that lived there: it was handed down from generation to generation and the family's ancestors were buried under its floor. Houses were built with mud bricks; reeds and wooden beams were used for ceilings, roofs, stairs, and furniture. Houses had to be maintained regularly; the inhabitants had to change the bricks and beams and renew the plaster of the roof and the walls. A woman awaiting the return of her eldest son to Ashur prepared the work:

Concerning the house in which we live, since the house was in disrepair, I was worried and had mud bricks made during the spring and I have piled them up. As for the wooden beams you wrote about, send me as much silver as you can so that one may buy beams here. (Michel 1997b, 2001: no. 320, forthcoming: no. 146; Veenhof 2011b)

The house was the domain par excellence of the woman, who wanted to possess a building as large and as nice as possible to show off the social success of her family. One woman, envying her neighbors, wrote to her husband: "Since you left, Šalim-ahum built two times a house; when will we be able to do (the same)?" (Michel 2001: no. 306; forthcoming: no. 147). The Old Assyrian commercial quarter in Ashur has not yet been located, thus we do not know if, as in Kaniš, the houses there had an upper story. According to sale contracts, the average merchant's house had a surface area of a hundred square meters and its price could vary from 5 to 15 minas of silver. Some houses are described as having a "main room" (ekallum; Michel 2001: no. 339, 1997b: 287). Because of the existence of a storage room containing archives and precious goods, it was important to guard the house at night and during the absence of its inhabitants. 
In Kaniš, Assyrians lived in the lower town. They bought houses built according to the local style; their average being 70-90 square meters, with some reaching over 150 or even 200 square meters (Özgüç 2003: 77-114). The two-story houses comprised a kitchen with an oven in its center, storerooms, and a sealed room. Some houses were organized around an open court. Their inhabitants lived and slept upstairs (Figure 4.4). According to their last wills, Assyrian merchants left their houses in Kaniš to their eldest sons or to their Anatolian wives.

Inside houses in Kaniš, various domestic objects were excavated; for example, clay and metal vessels such as bowls, vases, jars, pans, and cauldrons. Weapons and tools were found in the graves under the floor of some houses, including arrowheads, axes, spearheads, knives, pitchforks, shears, needles, nails, sickles, as well as other objects, such as divine statuettes, reels for spinning, gold and lapis lazuli jewelry, seals, and belt loops (Emre 2008; Kulakoğlu and Kangal 2010; Özgüç 2003: 142-281). Some rare texts record house inventories; one refers to the household of a woman that contained, among other things, grooved stands, lamps, bowls, measuring cups, various vessels, spoons, tables, containers, and cauldrons (Kt h/k 87; Dercksen 1996: 77; Michel forthcoming: no. 135).

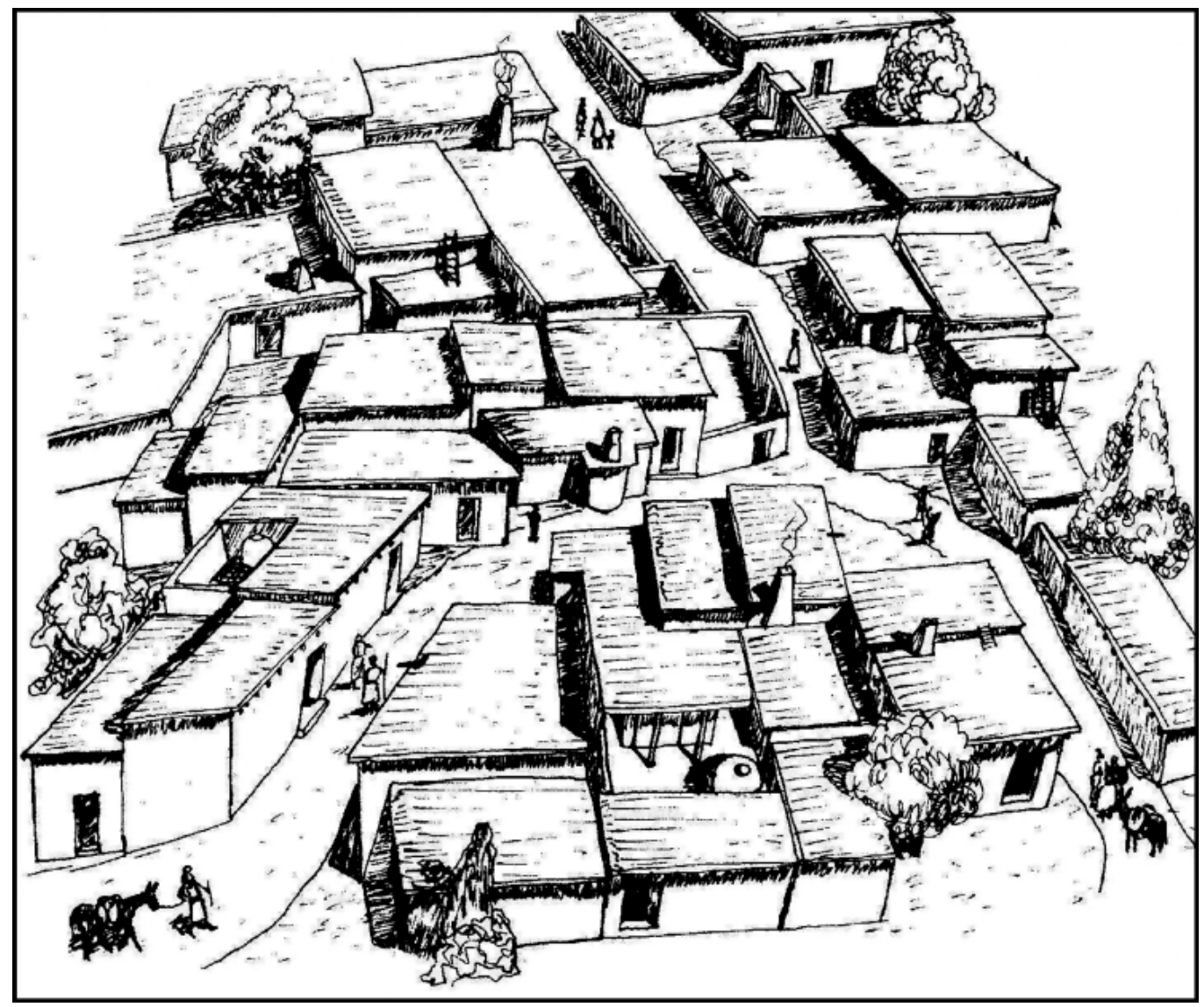

Figure 4.4 Private houses in the lower town level II, reconstruction. Source: Özgüç 2003: 106, no. 60. 


\section{Religion}

Since Old Assyrian texts deal mainly with trade, our knowledge of religion during this period is quite limited. Some texts refer to goods as belonging to temples or gods, e.g. gold and silver given as votive offerings ( $i k r i b \bar{u}$; Dercksen 1997), or refer to oaths taken in the name of various deities, who are also invoked as witnesses; they also refer to names of priests participating in the overland trade (Hirsch 1972). Many gods were venerated in Ashur, including Adad, Amurrum, Assur, Aššuritum, Belum, Ilabrat, Išḩara, Ištar the Star, Ištar.ZA.AT, Ninkarrak, Nisaba, Suen, Šamaš, Šarramaten, and Tašmetum (Eidem 2004; Dercksen 2005b; Kryszat 2003, 2006a, 2007b); among these, some also appear as family or personal gods, such as Amurrum, Ilabrat or Ištar.ZA.AT (Kryszat 2006b; Michel 1991: 85-8; Veenhof, 2014a). Most of these divine names also occur as parts of personal names (Veenhof $2008: 102-5$ ).

The main god was Assur, with whom the king of Ashur had special ties. The Assyrians had to take oaths on the weapon of Assur (patrum, šugariā'um; Donbaz 2001), which was kept in the sacred precinct (bamrum), while women took oaths on the tambourine of the goddess Isstar (Michel 1997c; forthcoming: no. 244-5). Girls consecrated to the god Assur did not belong to his temple but lived independently, perhaps nearby, certainly praying to the deity; but otherwise, we know nothing about their religious duties (see above, "Consecrated women").

The temples of Adad, Assur, Ištar, and Išhara served as warehouses for merchandise and votive offerings that they managed, but the treasure (massartum) of the god Assur might have been kept in the City Hall since it was under the responsibility of the steward (laputtā'um; Dercksen 2004a: 77-9; Matouš 1974b; Veenhof in this volume). In Kaniš, oaths were sworn at the gate of the god Assur, also called the sacred precinct, which might have represented a chapel dedicated to the god as part of the kārum office complex. Priests of Adad, Assur, Ištar, Suen, Šamaš, and Šarramaten are cited for their role in the trade: Mannuba, priest of Assur, was the recipient of silver earned from trade in Anatolia (TC 3, 203), and a priest of Suen possessed one of the few "houses" where it was possible to buy both tin and textiles that would be exported to Anatolia (TC 3, 129). Among the Ashur eponyms are Elali, the chief temple administrator (sangûm), and Iddin-Aššur, son of a priest (Veenhof 2003, Kryszat 2004).

Women's letters show their strong concern for religion: they made offerings to temples, paid tribute to gods, and reminded their husbands of their duties to the deities. Women involved in the public life of Ashur often had religious functions; several occupations linked to religion were traditionally held by women, such as dream interpreter $\left(s^{r} \bar{a}\right.$ ' iltum), diviner (bāritum), and consecrated woman (gubabtum, qadištum). Two women wrote to a close relative:

Here (in Ashur), we ask(ed) female dream interpreters, female diviners, and spirits of the dead; the god Assur gives you a serious warning. You love silver and despise your life! Can't you satisfy Assur here, in the City? Please, as soon as you have heard (the words of) the letter, come, see Assur's eye and save your life!” (Michel 2001: no. 348, 2009c, forthcoming: no. 253)

In each Assyrian trading post in Anatolia, there was a shrine or a sacred area devoted to Assur, where the god was represented by his statue with his weapon and jewelry. Other Assyrian deities were worshipped there too. Just as in Assur, Assyrians took oaths there, in front of the 
divine emblems of Assur. In the town of Uršu, in the area of Gaziantep, robbers once entered the Assur temple and stole the emblem and golden medallion of the god (Larsen: 261-62; Michel 2001: no. 51).

\section{Writing and archives}

Data about daily life come predominantly from the numerous letters found in the archives of merchants and exchanged between the different members of the family, and, more specifically, from the women's correspondences (Michel 2001; 2008d; Michel, forthcoming). Archives of an Assyrian family could include hundreds or more texts dealing, firstly, with the long-distance trade, and, secondly, with other topics, such as daily life. They were arranged on shelves along the walls of houses or in wooden boxes and clay jars with clay labels to specify their content (Larsen 2008; Michel 2008e; Veenhof 2003a, 2013). Envelopes of letters and contracts, as well as clay labels, bear cylinder seal imprints as a kind of signature and a mark of ownership; sealed legal texts were thus certified (Larsen 1997b; Tessier 1994). The syllabary in use during the Old Assyrian period is relatively simple, with no more than 150 to 200 signs, and with very few logograms and complex syllabic signs. Letters often seem to have been written by their authors - the need of the merchants to move around may explain why they did not use the services of scribes. Scribal apprenticeship could take place in the house of a master who taught a small number of pupils (CCT 4, 6e:4-16), but many learned the basics of writing at home, which allowed them to write their own correspondence and personal notes. Tablets perfectly formed and covered with a regular script can be distinguished from others that are awkwardly shaped and roughly written (Michel 2008a).

It is possible that not only men, but also some women learned how to read and write (Michel 2009d; forthcoming: chapter 4). Among the tablets sent, both by men and women, some display so many mistakes in signs and grammar that they were most likely written by the authors themselves.

\section{References}

Albayrak, İ. 2000. "Ein neues altassyrisches Testament aus Kültepe," Archivum Anatolicum 4, 17-27.

Atici, L. 2014. "Tracing Inequality from Assur to Kültepe/Kanesh: Merchants, Donkeys, and Clay Tablets," in: B.S. Arbuckle and S.A. McCarty (eds.), Animals and Inequality in the Ancient World, Boulder: University of Colorado Press, 233-52.

Balkan, K. 1986. "Betrothal of Girls during Childhood in Ancient Assyria and Anatolia," in: H.A. Hoffner and G.A. Beckman (eds.), Kanišuwar: A Tribute to Hans G. Güterbock on his Seventy-Fifth Birthday May 27, 1983, Assyriological Studies XXIII, Chicago: Oriental Institute, 1-11.

Barjamovic, G.J. 2014. "The Size of Kanesh and the Demography of Early Middle Bronze Age Anatolia," Journal of Cuneiform Studies, Suppl. Series 4, 55-68.

Barjamovic, G. 2015. "Contextualizing Tradition: Magic, Literacy and Domestic Life in Old Assyrian Kanesh," in: P. Delnero and J. Lauinger (eds.), Texts and Contexts. The Circulation and Transmission of Cuneiform Texts in Social Space, Berlin: De Gruyter, 48-86.

Barjamovic, G., Hertel, T.K., and Larsen, M.T. 2012. Ups and Downs at Kanesh: Chronology, History and Society in the Old Assyrian Period, PIHANS 120, Leiden: NINO. 
Dercksen, J.G. 1996. The Old Assyrian Copper Trade in Anatolia, PIHANS 75, Istanbul: NINO.

Dercksen, J.G. 1997. "The Silver of the Gods. On Old Assyrian ikribū," Archivum Anatolicum 3, 75-100.

Dercksen, J.G. 1999. "On the Financing of Old Assyrian Merchants," in: J.G. Dercksen (ed.), Trade and Finance in Ancient Mesopotamia, MOS Studies 1, Leiden: NINO, 85-99.

Dercksen, J.G. 2002. "Kultureller und wirtschaftlicher Austausch zwischen Assyrern und Anatoliern (Anfang des zweiten Jahrtausends v. Chr.)," in: H. Blum et al. (eds.), Brückenland Anatolien? Ursachen, Extensität und Modi des Kulturaustausches zwischen Anatolien und seinen Nachbarn, Tübingen: Attempo, 35-43.

Dercksen, J.G. 2004a. Old Assyrian Institutions, MOS Studies 4, Leiden: NINO.

Dercksen, J.G. 2004b. "Some Elements of Old Anatolian Society in Kaniš," in: J.G. Dercksen (ed.), Assyria and Beyond. Studies Presented to Mogens Trolle Larsen, PIHANS 100, Leiden, 137-78.

Dercksen, J.G. 2005a. "Metals According to the Documents from Kültepe-Kanish Dating to the Old Assyrian Colony Period," in: Ü. Yalcın (ed.), Anatolian Metal III, Der Anschnitt, Beiheft 18, Bochum: Deutsches Bergbau-Museum, 17-34.

Dercksen, J.G. 2005b. "Adad is King! The Sargon Text from Kültepe (with an appendix on MARV 4, 138 and 140)," Jaarbericht Ex Oriente Lux 39, 107-29.

Dercksen, J.G. 2007. "On Anatolian Loanwords in Akkadian Texts from Kültepe," Zeitschrift für Assyriologie 97, 26-46.

Dercksen, J.G. 2008a. "Subsistence, Surplus and the Market for Grain and Meat at Ancient Kanesh," in: G. Kryszat (ed.), Festschrift für Karl Hecker zum 75. Geburtstag am 25. Juli 2008, Altorientalische Forschungen 35, 86-102.

Dercksen, J.G. 2008b. "Observations on Land Use and Agriculture in Kaneš," in: C. Michel (ed.), Old Assyrian Studies in Memory of Paul Garelli, Old Assyrian Archives Studies 4, PIHANS 112, Leiden: NINO, 139-57.

Dercksen, J.G. 2015 "The Archive of Ali-ahum (I). The Documents Excavated in N-O-P/20 in 1950," in: F. Kulakoğlu and C. Michel (eds.), Proceedings of the 1st Kültepe International Meeting, Kültepe, 19-23 September, 2013, Subartu 35, Turnhout: Brepols, 47-58.

Donbaz, V. 2001. "Mabar patrim ša Ašsur: A New Interpretation,” in: W.H. van Soldt et al. (eds.), K. R. Veenhof Anniversary Volume, PIHANS 89, Leiden: NINO, 83-101.

Donbaz, V. 2003. “Lamniš ulā ezebsì. 'He Shall not Leave Her in a Bad Situation (Wickedly),'” in: G.J. Selz (ed.), Festschrift für Burkhart Kienast zu seinem 70. Geburtstage dargebracht von Freunden, Schülern und Kollegen, AOAT 274, Münster: Ugarit-Verlag, 47-50.

Edzard, D.O. 1989. "Altassyrisch Nuwa'um," in: K. Emre et al. (eds.), Anatolia and the Ancient Near East. Studies in Honour of Tahsin Özgüç, Ankara: Türk Tarih Kurumu Basımevi, 107-10.

Eidem, J. 2004. "In the Names of Aššur!," in: J.G. Dercksen (ed.), Assyria and Beyond. Studies Presented to Mogens Trolle Larsen, PIHANS 100, Leiden: NINO, 191-204.

Emre, K. 2008. "A Group of Metal Vessels from Kārum Kültepe/Kaneš,” in: C. Michel (ed.), Old Assyrian Studies in Memory of Paul Garelli, PIHANS 112, Leiden: NINO, 3-12.

Fairbairn, A. 2014. "Preliminary Archaeobotanical Investigations of Plant Production, Consumption, and Trade at Bronze Age Kültepe-Kanesh," Journal of Cuneiform Studies Suppl. Series 4, 171-91.

Garelli, P. 1963. Les Assyriens en Cappadoce, Bibliothèque archéologique et historique de l'Institut français d'archéologie d'Istanbul 19, Paris.

Goedegebuure, P.M. 2008. "Central Anatolian Languages and Language Communities in the Colony Period: A Luwian-Hattian Symbiosis and the Independent Hittites," in: J.G. Dercksen (ed.), Anatolia and the Jazira during the Old Assyrian Period, Old Assyrian Archives Studies 3, PIHANS 111, Leiden: NINO, 137-80.

Günbatt1, C. 2001. "The River Ordeal in Ancient Anatolia,” in: W.H. van Soldt et al. (eds.), K.R. Veenhof Anniversary Volume, PIHANS 89, Leiden: NINO, 151-60.

Günbatt1, C. 2004. "Two Treaty Texts Found at Kültepe," in: J.G. Dercksen (ed.), Assyria and Beyond: Studies Presented to Mogens Trolle Larsen, PIHANS 100, Leiden: NINO, 249-68. 
Haller, A., Andrae, W., and Hrouda, B. 1954. Die Gräber und Grüfte von Assur, WVDOG 65, Berlin: Gebr. Mann.

Hecker, K. 1997. "Über den Euphrat (Ortsbezogene Restriktionen in aA Kaufurkunden)," Archivum Anatolicum 3, 157-72.

Hecker, K. 2003. “Kunuk kārim saher rabi,” in: G.J. Selz (ed.), Festschrift für Burkhart Kienast zu seinem 70. Geburtstage dargebracht von Freunden, Schülern und Kollegen, AOAT 274, Münster: Ugarit-Verlag, 183-96.

Hecker, K. 2004a, “Altassyrische Texte,” in: B. Janowski and G. Wilhelm (eds.), Texte zum Rechts- und Wirtschaftsleben, Texte aus der Umwelt des Alten Testaments Neue Folge Bd. 1, Gütersloh: Gütersloher Verlagshaus, 43-57.

Hecker, K. 2004b. "Beim Tode unseres Vaters .... Der leidige Streit ums Erbe,” in: J.G. Dercksen (ed.), Assyria and Beyond. Studies Presented to Mogens Trolle Larsen, PIHANS 100, Leiden: NINO, 281-98.

Hertel, T.K. 2013. Old Assyrian Legal Practices. Law and Dispute in the Ancient Near East, Old Assyrian Archives Studies 6, PIHANS 123, Leiden: NINO.

Hertel, T.K. 2014. "The Lower Town of Kültepe: Urban Layout and Population," Journal of Cuneiform Studies Suppl. Series 4, 25-54.

Hertel, T.K. 2015. "Paternal Estates in Old Assyrian Society," in: F. Kulakoğlu and C. Michel (eds.), Proceedings of the 1st Kültepe International Meeting, Kültepe, 19-23 September, 2013, Subartu 35, Turnhout: Brepols, 29-43.

Hirsch, H. 1972. Untersuchungen zur altassyrischen Religion, AfO Beiheft 13/14, Osnabrück: Biblio.

Hockmann, D. 2010. Gräber und Grüfte in Assur, I. Von der zweiten Hälfte des 3. bis zur Mitte des 2. Jahrtausends v.Chr., WVDOG 129, Wiesbaden: Harrassowitz.

Ichisar, M. 1981. Les archives cappadociennes du marchand Imdīlum, Paris: A.D.P.F.

Kienast, B. 1984. Das altassyrische Kaufvertragsrecht, FAOS Beiheft 1, Stuttgart: Steiner.

Kienast, B. 2008. "Altassyrisch amtum = 'Zweitfrau," in: G. Kryszat (ed.), Festschrift für Karl Hecker zum 75. Geburtstag am 25. Juli 2008, Altorientalische Forschungen 35, 35-52.

Kienast, B. 2015. Das altassyrische Eherecht. Eine Urkundenlehre, SANTAG 10, Wiesbaden: Harrassowitz-Verlag.

Kouwenberg, B. and Fincke, J.C. 2013. "A 'New' Old Assyrian Incantation,” Jaarbericht Ex Oriente $\operatorname{Lux} 44,141-6$.

Kryszat, G. 2003. "Altassyrischer Brief an die Göttin Tašmētum,” in: G.J. Selz (ed.), Festschrift für Burkhart Kienast zu seinem 70. Geburtstage dargebracht von Freunden, Schülern und Kollegen, AOAT 274, Münster: Ugarit-Verlag, 251-8.

Kryszat, G. 2004. Zur Chronologie der Kanfmannsarchive aus der Schicht 2 des Kārum Kaneš, Old Assyrian Archives Studies 2, PIHANS 99, Leiden: NINO.

Kryszat, G. 2006a. "Altassyrische Miszellen 2, Zur Göttin Ištar-ZA.AT," Archiv für Orientforschung $51,247-8$.

Kryszat, G. 2006b. "Die altassyrischen Belege für den Gott Amurru," Zeitschrift für Assyriologie 100, $53-6$.

Kryszat, G. 2007a. "Eine Dame mit Namen Zizizi," Altorientalische Forschungen 34, 210-18.

Kryszat, G. 2007b. "Zur Liste der Schwurgötter im Assur-Apûm-Vertrag," in: J.M. Córdoba and P.A. Miglus (eds.), Assur und sein Umland, Isimu 6, 99-102.

Kryszat, G. 2008a. "Herrscher, Kult und Kulttradition in Anatolien nach den Quellen aus den altassyrischen Handelskolonien. Teil 3/1: Grundlagen für eine neue Rekonstruktion der Geschichte Anatoliens und der assyrischen Handelskolonien in spätaltassyrischer Zeit,” in: G. Kryszat (ed.), Festschrift für Karl Hecker zum 75. Geburtstag am 25. Juli 2008, AoF 35, 156-89.

Kryszat, G. 2008b. "Herrscher, Kult und Kulttradition in Anatolien nach den Quellen aus den altassyrischen Handelskolonien. Teil 3/2: Grundlagen für eine neue Rekonstruktion der Geschichte Anatoliens und der assyrischen Handelskolonien in spätaltassyrischer Zeit II," in: G. Kryszat (ed.), Festschrift für Karl Hecker zum 75. Geburtstag am 25. Juli 2008, AoF 35, 195-219. 
Kulakoğlu, F. and Kangal, S. 2010. Anadolu'nun Önsözü Kültepe Kaniş-Karumu. Asurlular İstanbul'da/Anatolia's Prologue Kültepe Kanesh Karum. Assyrians in Istanbul, Kayseri Metropolitan Municipality Cultural Publication 78, Istanbul: Kayseri Metropolitan Municipality.

Larsen, M.T. 1967. Old Assyrian Caravan Procedures, PIHANS 22, Istanbul: NHAI.

Larsen, M.T. 1976. The Old Assyrian City-State and its Colonies, Mesopotamia 4, Copenhagen: Akademisk Forlag.

Larsen, M.T. 1977a. "Partnerships in the Old Assyrian Trade," Iraq 39, 119-49.

Larsen, M.T. 1977b. "Seal Use in the Old Assyrian Period," in: M. Gibson and D. Biggs (eds.), Seals and Sealing in the Ancient Near East, BM 6, Malibu, 89-105.

Larsen, M.T. 1982. "Your Money or Your Life! A Portrait of an Assyrian Businessman," in: M.A. Dandamayev et al. (eds.), Societies and Languages of the Ancient Near East. Studies in Honor of I. M. Diakonoff, Warminster: Aris \& Phillips, 214-45.

Larsen, M.T. 2001. "Affect and Emotion," in: W.H. van Soldt et al. (eds.), K. R. Veenhof Anniversary Volume, PIHANS 89, Leiden: NINO, 275-86.

Larsen, M.T. 2002. The Ašsur-nādā Archive, Old Assyrian Archives Studies 1, Leiden: NINO.

Larsen, M.T. 2007. "Individual and Family in Old Assyrian Society," Journal of Cuneiform Studies 59, 93-106.

Larsen, M.T. 2008. "Archives and Filing Systems at Kültepe," in: C. Michel (ed.), Old Assyrian Studies in Memory of Paul Garelli, Old Assyrian Archives Studies 4, PIHANS 112, Leiden: NINO, 77-88.

Larsen, M.T. 2010. The Archive of the Šalim-Ašsur Family, vol. 1: The First Two Generations, Kültepe Tabletleri 6, Ankara: Türk Tarih Kurumu.

Larsen, M.T. 2015. Ancient Kanesh. A Merchant Colony in Bronze Age Anatolia, Cambridge: Cambridge University Press.

Lassen, A.W. 2010. "Tools, Procedures and Professions: A Review of the Akkadian Textile Terminology," in: C. Michel and M.-L. Nosch (eds.), Textile Terminologies in the Ancient Near East and Mediterranean from the Third to the First Millennia BC, Ancient Textiles Series 8, Oxford: Oxbow, 272-82.

Lehner, J. 2014. "Metal Technology, Organization, and the Evolution of Long-Distance Trade at Kültepe," Journal of Cuneiform Studies Suppl. Series 4, 135-56.

Lion, B., Michel, C., and Noël, P. 2000. "Les crevettes dans la documentation du Proche-Orient ancien," Journal of Cuneiform Studies 52, 55-60.

Matouš, L. 1974. "Der Aššur-Tempel nach altassyrischen Urkunden aus Kültepe," in: M.S. Heerma et al. (eds.), Travels in the World of the Old Testament. Studies Presented to Professor M.A. Beek, Assen: Van Gorcum, 181-9.

Michel, C. 1991. Innāya dans les tablettes paléo-assyriennes, Paris: ERC.

Michel, C. 1995. "Validité et durée de vie des contrats et reconnaissances de dette paléo-assyriens," Revue d'Assyriologie 89, 15-27.

Michel, C. 1997a. "A table avec les marchands paléo-assyriens," in: H. Waetzold and H. Hauptmann (eds.), Assyrien im Wandel der Zeiten, HSAO 6, Heidelberg: Orient-Verlag, 95-113.

Michel, C. 1997b. "Propriétés immobilières dans les tablettes paléo-assyriennes," in: K.R. Veenhof (ed.), Houses and Households in Ancient Mesopotamia, PIHANS 78, Leiden: NINO, 285-300.

Michel, C. 1997c. "Hommes et femmes prêtent serment à l'époque paléo-assyrienne," in: S. DémareLafont (ed.), "Jurer et maudire". Pratiques politiques et usages juridiques du serment dans le ProcheOrient ancien, Méditerranées 10-11, 105-23.

Michel, C. 1997d. "Les enfants des marchands de Kaniš," in: B. Lion et al. (eds.), Enfance et éducation au Proche-Orient ancien, Actes de la table ronde, Nanterre, Décembre 1997, Ktèma 22, 91-108.

Michel, C. 1997e. "Une incantation paléo-assyrienne contre Lamaštum," Orientalia 66, 58-64.

Michel, C. 2000. "À propos d'un testament paléo-assyrien: une femme 'père et mère' des capitaux," Revue d'Assyriologie 94, 1-10.

Michel, C. 2001. Correspondance des marchands de Kaniš au début du IIe millénaire av. J.-C., Littératures du Proche-Orient ancien 19, Paris: Cerf. 
Michel, C. 2003. Old Assyrian Bibliography of Cuneiform Texts, Bullae, Seals and the Results of the Excavations at Ašsur, Kültepe/Kaniš, Acemböyük, Alişar and Boğazköy, Old Assyrian Archives Studies 1, PIHANS 97, Leiden: NINO.

Michel, C. 2003a. "Les femmes et les dettes: problèmes de responsabilité dans la Mésopotamie du IIe millénaire avant J.-C.," Méditerranées 34-5, 13-36.

Michel, C. 2004. "Deux incantations paléo-assyriennes. Une nouvelle incantation pour faciliter la naissance," in: J.G. Dercksen (ed.), Assyria and Beyond: Studies Presented to Mogens Trolle Larsen, PIHANS 100, Leiden: NINO, 395-420.

Michel, C. 2005. "Le commerce privé des Assyriens en Anatolie modèle du commerce archaïque selon K. Polanyi," in: P. Clancier (ed.), Autour de Polanyi, vocabulaires, théories et modalités des échanges, Paris: De Boccard, 121-33.

Michel, C. 2006a. "Calculer chez les marchands assyriens du début du IIe millénaire av. J.-C.," Website CultureMaths http://culturemath.ens.fr/histoire des maths/htm/Michel06/Michel06.pdf.

Michel, C. 2006b. "Bigamie chez les Assyriens du début du IIe millénaire," Revue Historique de Droit Français et Etranger 84, 155-76.

Michel, C. 2006c. "Les suidés dans la documentation de Kaniš au début du IIe millénaire avant J.-C.," in: B. Lion and C. Michel (eds.), De la domestication au tabou: le cas des suidés au Proche-Orient ancien, Actes du colloque international, Nanterre, 1-3 décembre 2005, Paris: De Boccard, 169-80.

Michel, C. 2006d. "Femmes et production textile à Aššur au début du IIe millénaire avant J.-C.," Techniques er culture 46, 281-97.

Michel, C. 2008a. "Écrire et compter chez les marchands assyriens du début du IIe millénaire av. J.-C.," in: T. Tarhan et al. (eds.), Mubibbe Darga Armağam, Istanbul: Sadbek Hanim Muzesi, 345-64.

Michel, C. 2008b. “'Tu aimes trop l'argent et méprises ta vie.' Le commerce lucratif des Assyriens en Anatolie centrale," in: La richessa nel Vicino Oriente Antico, Atti del Convegno internazionale Milano 20 gennaio 2007, Centro Studi del Vicino Oriente, Milan: Ares, 37-62.

Michel, C. 2008c. "Les Assyriens et leurs femmes anatoliennes," in: J.G. Dercksen (ed.), Anatolia and the Jazira during the Old Assyrian Period, Old Assyrian Archives Studies 3, PIHANS 111, Leiden: NINO, 209-29.

Michel, C. 2008d. "La correspondance des marchands assyriens du XIXe s. av. J.-C.: de l'archivage des lettres commerciales et privées," in: L. Pantalacci (ed.), La lettre d'archive. Communication administrative et personnelle dans l'Antiquité proche-orientale et égyptienne, Topoi Suppl. 9, Cairo: Institut français d'archeologie orientale, 117-40.

Michel, C. 2008e. "The Alāhum and Aššur-taklāku archives found in 1993 at Kültepe Kaniš," in: G. Kryszat (ed.), Festschrift für Karl Hecker zum 75. Geburtstag am 25. Juli 2008, AoF 35, 53-67.

Michel, C. 2008f. "Les Assyriens et les esprits de leurs morts," in: C. Michel (ed.), Old Assyrian Studies in Memory of Paul Garelli, Old Assyrian Archives Studies 4, PIHANS 112, Leiden: NINO, 181-97.

Michel, C. 2009a. “'Dis-moi ce que tu bois ... ': Boissons et buveurs en haute Mésopotamie et Anatolie au début du IIe millénaire av. J.-C.," in: X. Faivre et al. (eds.), Et il y eut un esprit dans l'Homme. Jean Bottéro et la Mésopotamie, Paris: De Boccard, 197-220.

Michel, C. 2009b. "Femmes et ancêtres: le cas des femmes des marchands d'Aššur," in: F. BriquelChatonnet, S. Fares, B. Lion, and C. Michel (eds.), Femmes, cultures et sociétés dans les civilisations méditerranéennes et proches-orientales de l'Antiquité, Topoi Suppl. 10, Cairo: Institut français d'archeologie orientale, 27-39.

Michel, C. 2009c. "Les filles de marchands consacrées," in: F. Briquel-Chatonnet et al. (eds.), Femmes, cultures et sociétés dans les civilisations méditerranéennes et proches-orientales de l'Antiquité, Topoi Suppl. 10, Cairo: Institut français d'archeologie orientale, 145-63.

Michel, C. 2009d. "Les femmes et l'écrit dans les archives paléo-assyriennes (XIXe s. av. J.-C.)," in: F. Briquel-Chatonnet et al. (eds.), Femmes, cultures et sociétés dans les civilisations méditerranéennes et proches-orientales de l'Antiquité, Topoi Suppl. 10, Le Caire: Institut français d'archeologie orientale, 253-72. 
Michel, C. 2010. "Les comptoirs de commerce assyriens en Anatolie: emprunts réciproques et acculturation," in: P. Rouillard (ed.), Portraits de migrants, portraits de colons II, Paris: De Boccard, 1-12.

Michel, C. 2011 a. "The Kārum Period on the Plateau," in: S.R. Steadman and G. McMahon (eds.), Oxford Handbook of Ancient Anatolia (10,000-323 BCE), Oxford: Oxford University Press, 313-36.

Michel, C. 2011b. "The Private Archives from Kaniš Belonging to Anatolians," Altorientalische Forschungen 38, 94-115.

Michel, C. 2013a. "Old Assyrian Kaniš (Akkadian Texts: Women in Letters)," in: M.W. Chavalas (ed.), Women in the Ancient Near East, London and New York: Routledge, 205-12.

Michel, C. 2013b. "Economic and Social Aspects of the Old Assyrian Loan Contract," in: F. D'Agostino (ed.), L'economia dell'antica Mesopotamia (III-I millennio a.C.): Per un dialogo interdisciplinare, La Sapienza Orientale 9, Rome: Nuova Cultura, 41-56.

Michel, C. 2014a. "Central Anatolia in the Nineteenth and Eighteenth Centuries BC," in: N. Brisch et al. (eds.), Constituent, Confederate, and Conquered Space: The Emergence of the Mittani State, TOPOI, Berlin Studies of the Ancient World 17, 113-38.

Michel, C. 2014b. "Considerations on the Assyrian Settlement at Kaneš," Journal of Cuneiform Studies Suppl. Series 4, 69-84.

Michel, C. 2014c. "Wool Trade in Upper Mesopotamia and Syria According to Old Babylonian and Old Assyrian Texts," in: C. Breniquet and C. Michel (eds.), Wool Economy in the Ancient Near East and the Aegean: From the Beginnings of Sheep Husbandry to Institutional Textile Industry, Ancient Textiles Series 17, Oxford: Oxbow Books, 232-54.

Michel, C. 2014d. "Se restaurer en route en haute Mésopotamie et Anatolie au début du II millénaire avant J.-C.," in : L. Milano (ed.), Paleonutrition and Food Practices in the Ancient Near East: Towards a Multidisciplinary Approach, Padua: SARGON, 309-26.

Michel, C. 2015a. "Les lettres des rois d'Aššur découvertes à Kaniš (xix e siècle av. J.-C.), in: S. Procházka, L. Reinfandt, and S. Tost (eds.), Official Epistolography and the Language(s) of Power. Proceedings of the First International Conference of the Research Network Imperium o Officium, Comparative Studies in Ancient Bureaucracy and Officialdom. University of Vienna, 10-12 November 2010, Papyrologica Vindobonensia 8, Vienna: Verlag der Österreichischen Akademie der Wissenschaften, 43-60.

Michel, C. 2015b. "Were There Only Merchants at Aššur and Kaneš? Overview of Professions Attested in the Old Assyrian Sources," in: I. Albayrak et al. (eds.), Cahit Günbattı Armağan: Studies in Honour of Cahit Günbattı, Ankara: Ankara Üniversitesi Dil ve Tarih Coğrafya Fakültesi, 171-84.

Michel, C. 2015c. "Women in the Family of Ali-ahum Son of Iddin-Suen (1993 Kültepe Archive)," in: F. Kulakoğlu and C. Michel (eds.), Proceedings of the 1st Kültepe International Meeting, Kültepe, 19-23 September, 2013, Subartu 35, Turnhout: Brepols, 85-93.

Michel, C. In press. "Weighing Units and Weights in the Context of Trade from Upper Mesopotamia to Anatolia (Nineteenth and Eighteenth Centuries BCE)," in: K. Chemla, A. Keller, and C. Proust (eds.), Cultures of Quantification and Computation, Why Sciences of the Ancient World Matter 1, Berlin/Heidelberg: Springer Verlag.

Michel, C. Forthcoming. Women from Ašsur and Kaniš, Writings from the Ancient World, Baltimore: SBL.

Michel, C. and Garelli, P. 1996. "Heurts avec une principauté anatolienne," in: A.A. Ambros and M. Köhbach (eds.), Festschrift für Hans Hirsch zum 65. Geburtstag gewidmet von seinen Freunden, Kollegen und Schülern, Wiener Zeitschrift für die Kunde des Morgenlandes 86, 277-90.

Michel, C. and Veenhof, K.R. 2010. "The Textiles traded by the Assyrians in Anatolia (19th-18th Centuries BC)," in: C. Michel and M.-L. Nosch (eds.), Textile Terminologies in the Ancient Near East and Mediterranean from the Third to the First millennia BC, Ancient Textiles Series 8, Oxford: Oxbow, 209-69.

Özgüç, T. 2003. Kültepe Kaniš/Neša: The Earliest International Trade Center and the Oldest Capital City of the Hittites, Tokyo: Middle Eastern Culture Center in Japan. 
Rems, R. 1996. "Eine Kleinigkeit zum altassyrischen Eherecht," in: A.A. Ambros and M. Köhbach (eds.), Festschrift für Hans Hirsch zum 65. Geburtstag gewidmet von seinen Freunden, Kollegen und Schülern, Wiener Zeitschrift für die Kunde des Morgenlandes 86, 355-67.

Sever, H. 1992. "Eine neue Ehescheidungsurkunde," in: H. Otten et al. (eds.), Hittite and other Anatolian and Near Eastern Studies in Honour of Sedat Alp, Ankara: Anadolu Medeniyetleri Arastirma ve Tanitma Vakfi Yayinlari, 483-6.

Sturm, T. 2001. "Puzur-Annā: Ein Schmied des Kārum Kanišs," in: W.H. van Soldt et al. (eds.), K.R. Veenhof Anniversary Volume, PIHANS 89, Leiden: NINO, 475-501.

Ulshöfer, A. 2000. "Sprachbarrieren und ihre Überwindung: Translatorisches Handeln im alten Orient," in: L. Milano (ed.), Landscapes, Territories, Frontiers and Horizons in the Ancient Near East. Papers Presented to the XLIVth Rencontre Assyriologique Internationale Venezia, 7-11 July, 1997, History of the Ancient Near East/Monographs III/1-3, Padova: Sargon, 163-9.

Üstündağ, H. 2014. "Human Remains from Kültepe/Kanesh: Preliminary Results of the Old Assyrian Burials from the 2005-2008 Excavations," Journal of Cuneiform Studies Suppl. Series 4, 157-73.

Veenhof, K.R. 1972. Aspects of the Old Assyrian Trade and its Terminology, Studia et Documenta ad Iura Orientis Antiqui Pertinentia 10, Leiden: Brill.

Veenhof, K.R. 1982a. "The Old Assyrian Merchants and Their Relations with the Native Population of Anatolia," in: H. Kühne et al. (eds.), Mesopotamien und seine Nachbarn. Politische und kulturelle Wechselbeziehungen im Alten Vorderasien vom 4. bis 1. Jahrtausend v. Chr., Berliner Beiträge zum Vorderen Orient 1, Berlin: Reimer, 147-55.

Veenhof, K.R. 1982c. "A Deed of Manumission and Adoption from the Later Old Assyrian Period," in: G.V. Driel et al. (eds.), Zikir šumim. Assyriological Studies Presented to F.R. Kraus on the Occasion of his Seventieth Birthday, Leiden: Brill, 359-85.

Veenhof, K.R. 1994. "Miete. C. Altassyrisch,” Reallexikon der Assyriologie 8, 181-4.

Veenhof, K.R. 1995. “'In Accordance with the Words of the Stele.' Evidence for Old Assyrian Legislation," Chicago-Kent Law Review 70, 1717-44.

Veenhof, K.R. 1997a. "'Modern' Features in Old Assyrian Trade," Journal of the Economic and Social History of the Orient 40, 336-66.

Veenhof, K.R. 1997b. "Two Marriage Documents from Kültepe," Archivum Anatolicum 3, 357-81.

Veenhof, K.R. 1998. "Old Assyrian and Ancient Anatolian Evidence for the Care of the Elderly," in: M. Stol and S.P. Vlemings (eds.), The Care of the Elderly in the Ancient Near East, Leiden: Brill, 119-60.

Veenhof, K.R. 1999a. "Silver and Credit in Old Assyrian Trade," in: J.G. Dercksen (ed.), Trade and Finance in Ancient Mesopotamia, MOS Studies 1, Leiden: NINO, 55-83.

Veenhof, K.R. 1999b. "Redemption of Houses in Assur and Sippar," in: B. Böck et al. (eds.), Munuscula Mesopotamica. Festschrift für Johannes Renger, AOAT 267, Münster: Ugarit-Verlag, 599-616.

Veenhof, K.R. 2001. "The Old Assyrian Period," in: R. Westbrook and R. Jasnow (eds.), Security for Debt in Ancient Near Eastern Law, Leiden: Brill, 93-159.

Veenhof, K.R. 2003. The Old Assyrian List of Year Eponyms from Karum Kanish and its Chronological Implications, TTKY IV/64, Ankara: Türk Tarih Kurumu.

Veenhof, K.R. 2003a. "Archives of Old Assyrian Traders," in: M. Brosius (ed.), Archives and Archival Tradition. Concepts of Record Keeping in the Ancient World, Oxford: Oxford University Press, 78-123.

Veenhof, K.R. 2003b. “Old Assyrian Period," in: R. Westbrook (ed.), A History of Ancient Near Eastern Law, vol. 1, Handbuch der Orientalistik, Section I, vol. 72/1, Leiden: Brill, 431-84.

Veenhof, K.R. 2003c. "Trade and Politics in Ancient Assur. Balancing of Public, Colonial and Entrepreneurial Interests," in: C. Zaccagnini (ed.), Mercante e Politica nel Mondo Antico, Saggi di Storia Antica 21, Rome: L'Erma di Bretschneider, 69-118.

Veenhof, K.R. 2007. "Sisterly Advice on an Endangered Marriage in an Old Assyrian Letter," in: M. Roth et al. (eds.), Studies Presented to Robert D. Biggs, June 4, 2004, From the Workshop of the Chicago Assyrian Dictionary II, Chicago: Oriental Institute, 285-304. 
Veenhof, K.R. 2008. "The Old Assyrian Period," in: M. Wäfler (ed.), Mesopotamia. The Old Assyrian Period, Annäherungen 5, OBO 160/5 Teil 1, Fribourg and Göttingen: Vandenhoeck \& Ruprecht, 13-264.

Veenhof, K.R. 2008a. "The Death and Burial of Ishtar-Lamassi in karum Kanish,” in: R.J. van der Spek (ed.), Studies in Ancient Near Eastern World View and Society Presented to Marten Stol on the Occasion of His 65th Birthday, 10 November 2005, and His Retirement from the Vrije Universiteit, Amsterdam, Bethesda: CDL, 97-119.

Veenhof, K.R. 2010. “Ancient Assur. The City, its Traders, and its Commercial Network," JESHO 53, 39-82.

Veenhof, K.R. 2011 a. "Last Wills and Inheritance of Old Assyrian Traders with Four Records from the Archive of Elamma," in: K. Abraham and J. Fleishman (eds.), Family Cohesion in the Bible and the Ancient Near East: Studies in Honour of Aaron Skaist on the Occasion of his 76th Birthday, Bethesda: CDL, 169-201.

Veenhof, K.R. 2011 b. “Houses in the Ancient City of Assur," in: B.S. Dünring et al. (eds.), Correlates of Complexity: Essays in Archaeology and Assyriology Dedicated to Diederik J. W. Meijer in Honour of his 65th Birthday, PIHANS 116, Leiden: NINO, 211-31.

Veenhof, K.R. 2013. "The Archives of Old Assyrian Traders: Their Nature, Functions and Use," in: M. Faraguna (ed.), Archives and Archival Documents in Ancient Societies: Legal Documents in Ancient Societies 4, Trieste: EUT Edizioni Università di Trieste, 27-71.

Veenhof, K.R. 2014a. "Families of Assyrian Traders," in: L. Marti (ed.), La famille dans le ProcheOrient ancien: réalités, symbolismes et images, Proceedings of the 55th Rencontre Assyriologique Internationale at Paris, 6-9 July 2009, Winona Lake: Eisenbrauns, 341-71.

Veenhof, K.R. 2014b. "Silver in Old Assyrian Trade. Its Shapes, Qualities and Purification," in: Z. Csabai (ed.), Studies in Economic and Social History of the Ancient Near East in Memory of Péter Vargyas, Ancient Near Eastern and Mediterranean Studies 2, Budapest: L'Harmattan Hungary, 387-416.

Von Soden, W. 1956. "Eine altassyrische Beschwörung gegen die Dämonin Lamaštum," Orientalia $25,141-8$.

Wilhelm, G. 2008. "Hurrians in the Kültepe Texts," in: J.G. Dercksen (ed.), Anatolia and the Jazira during the Old Assyrian Period, Old Assyrian Archives Studies 3, PIHANS 111, Leiden, 181-94.

\section{Further Reading}

There is no book entirely dedicated to Old Assyrian society, but many articles concern topics related to this theme. Information on the citizens of Ashur and Kaniš is provided by Barjamovic 2014, Hertel 2013, 2014, Larsen 2015, Veenhof 1995a, and, with regard to slaves, Kienast 1984. Assyrian families are studied by Michel 2001: chapter 6 and Veenhof 2014a; for the family as a commercial network, see Larsen 2007. A sample of one hundred women's letters is provided in Michel 2001: chapter 7; see also Michel 2013a, 2015c and, for Assyrian and Anatolian women, Michel (forthcoming), which deals with marriage and divorce (see also Michel 2006b), the place of women in the family, maternity, housewives, businesswomen, and the moral and religious values of women; it also gives some three hundred texts in translation. Children are studied in Michel 1997d. For inheritance practices and last wills, see Hecker 2004a, 2004b, Michel 2000b and Veenhof 201 la. Michel 2008f, 2009b, Veenhof 1998, and 2008a deal with death and burials. For agriculture, cattle breeding, and food production, see Atici 2014, Dercksen 2008a, 2008b, Fairbairn 2014, Michel 1997a, 2006c, 2008c, 2009a, 2014d; for houses and their inventories Kulakoğlu and Kangal 2010, Michel 1997b and Veenhof 2011b; and for textiles Michel 2006d, Michel and Veenhof 2010. Data about markets, craftsmen, and loan contracts may be found in Dercksen 2004a, Michel 2013b, 2015b, and Veenhof 2008. An overview of Old Assyrian religion is presented in Hirsch 1972; Kryszat 2003, 2006a, 2006b and 2007b are focused on specific gods, while Michel 2009c discusses the role of consecrated girls; see also Michel (forthcoming): chapter 5. Old Assyrian writing, counting, and metrology are analyzed in Barjamovic 2015, Michel 2006a, 2008a, and in press. 